\title{
Ligand Binding to Heparan Sulfate Proteoglycans Induces Their Aggregation and Distribution along Actin Cytoskeleton
}

\author{
Rui G. Martinho, ${ }^{*+}$ Susanna Castel, Jesus Ureña, ${ }^{*}$ Mar Fernández-Borja, ${ }^{*}$ \\ Ricardo Makiya, ${ }^{*}$ Gunilla Olivecrona, ${ }^{\ddagger}$ Manuel Reina, ${ }^{*}$ Ana Alonso, ${ }^{\mathbb{\$}}$ and \\ Senén Vilaró $* \|$
}

*Departamento de Biologia Celular, Universidad de Barcelona, 08028-Barcelona, Spain; ${ }^{\S}$ Departamento de Biologia Celular y Ciencias Morfológicas, Universidad del País Vasco, 48940-Leioa, Bilbao, Spain; and ${ }^{\ddagger}$ Department of Medical Biochemistry, University of Umeå, S-90187 Umeå, Sweden

Submitted January 11, 1996; Accepted August 16, 1996

Monitoring Editor: Masatoshi Takeichi

Cell surface heparan sulfate proteoglycans (HSPGs) participate in molecular events that regulate cell adhesion, migration, and proliferation. The present study demonstrates that soluble heparin-binding proteins or cross-linking antibodies induce the aggregation of cell surface HSPGs and their distribution along underlying actin filaments. Immunofluorescence and confocal microscopy and immunogold and electron microscopy indicate that, in the absence of ligands, HSPGs are irregularly distributed on the fibroblast cell surface, without any apparent codistribution with the actin cytoskeleton. In the presence of ligand (lipoprotein lipase) or antibodies against heparan sulfate, HSPGs aggregate and colocalize with the actin cytoskeleton. Triton X-100 extraction and immunoelectron microscopy have demonstrated that in this condition HSPGs were clustered and associated with the actin filaments. Crosslinking experiments that use biotinylated lipoprotein lipase have revealed three major proteoglycans as binding sites at the fibroblast cell surface. These cross-linked proteoglycans appeared in the Triton X-100 insoluble fraction. Platinum/carbon replicas of the fibroblast surface incubated either with lipoprotein lipase or antiheparan sulfate showed large aggregates of HSPGs regularly distributed along cytoplasmic fibers. Quantification of the spacing between HSPGs by confocal microscopy confirmed that the nonrandom distribution of HSPG aggregates along the actin cytoskeleton was induced by ligand binding. When cells were incubated either with lipoprotein lipase or antibodies against heparan sulfate, the distance between immunofluorescence spots was uniform. In contrast, the spacing between HSPGs on fixed cells not incubated with ligand was more variable. This highly organized spatial relationship between actin and proteoglycans suggests that cortical actin filaments could organize the molecular machinery involved in signal transduction and molecular movements on the cell surface that are triggered by heparin-binding proteins.

\section{INTRODUCTION}

There is growing evidence that the interaction between plasma membrane proteins and the actin cytoskeleton is important for signal transduction and the

\footnotetext{
+ Present address: MRC-Cell Mutation Unit, Sussex University, Falmer, Brighton, BNI 9RR, United Kingdom.

"Corresponding author: Departamento de Biologia Celular, Universidad de Barcelona, Avda. Diagonal, 645, 08028-Barcelona, Spain.
}

regulation of cell growth and differentiation. Integrins, the major cell matrix adhesion molecules, were the first to be discovered interacting with the actin cytoskeleton at specific sites of the plasma membrane, called focal contacts (Hynes, 1992). Through their cytoplasmic tail, integrins interact with actin-binding proteins, which in turn have a clear role in the cell organization of actin filaments. The binding of integrins to their extracellular ligands (e.g., fibronectin) induces the phosphorylation of focal contact-associ- 
ated proteins, modulating the cytoskeletal organization during adhesion to the extracellular matrix (recently reviewed, Yamada and Miyamoto, 1995) and initiating signal transduction across the plasma membrane. The integrin-mediated signaling is triggered by a cytoplasm-bound tyrosine kinase (focal adhesion kinase, FAK) that associates with $\beta_{1}$ integrin molecules when aggregated by antibodies or ligands. Recent evidence (recently reviewed, Gumbiner, 1995) has also shown that cadherins, major members of the family of cell-cell adhesion molecules, also interact with the actin cytoskeleton, this interaction being involved in the establishment of epithelial morphology. Intracellular proteins, called catenins, and tyrosine kinase substrates mediate the interaction of cadherins with the actin cytoskeleton. Several lines of evidence also indicate that plasma membrane heparan sulfate proteoglycans (HSPGs), ${ }^{1}$ abundant components of all cell surfaces, also interact with the actin cytoskeleton (recently reviewed, David, 1993; Rapraeger, 1993; Elenius and Jalkanen, 1994), but the precise mode of interaction and function has remained elusive.

Heparin-binding proteins share their affinity for binding to the glycosaminoglycan chains of HSPGs. They constitute a diverse group of proteins, which includes extracellular matrix molecules, growth factors, degradative and lipolytic enzymes, protease inhibitors, lipoproteins, nuclear proteins, and viral coat proteins (Kjellén and Lindahl, 1991; Bernfield et al., 1992). Growing evidence indicates that HSPGs participate in a dual receptor system (Klagsbrun and Baird, 1991) in which the low-affinity cell surface HSPGs deliver or facilitate the interaction of soluble proteins to high-affinity receptors (Schlessinger $e t$ al., 1995). For instance, HSPGs act as a low-affinity receptor for fibroblast growth factor 2 (FGF-2) and are involved in the presentation of the growth factor to its "highaffinity receptor," a tyrosine kinase receptor responsible for the signaling effects of FGF-2 (Rapraeger et al., 1991; Yayon et al., 1991; Olwin and Rapraeger, 1992). In addition, it has been suggested that heparan sulfate (HS) could bind directly to FGF receptors (Kan et al., 1993). Because all of the known members of the FGF family bind heparin, the dependence of FGF-2 binding and bioactivity on a dual receptor system may not be unique. FGF-1 activity in a parathyroid cell line (Sakagushi et al., 1991), heregulin (Holmes et al., 1992), heparin-binding epidermal growth factor (EGF)-like growth factor (a member of the EGF family) activity in smooth muscle cell migration (Higashiyama et al., 1993), and vascular endothelial growth factor-binding to its receptors (Gitay-Goren et al., 1992) are all dependent on interactions with cell surface HSPGs. The

\footnotetext{
${ }^{1}$ Abbreviations used: FGF-2, fibroblast growth factor 2; HS, heparan sulfate; HSPGs, heparan sulfate proteoglycans; LPL, lipoprotein lipase; PGs, proteoglycans.
}

physiological role of such a dual receptor system is not clear, but it recently has been suggested (Schlessinger et al., 1995) that the binding of FGF to HSPGs by restricting ligand diffusion may allow the cell surface encounters with the high-affinity signaling receptors and that the formation of a multivalent FGF-HSPG complex is required for FGF-induced dimerization of the signaling receptors. Lipoprotein lipase (LPL, another well-known heparin-binding protein) is anchored by HSPGs on the endothelial surface, where it exerts its lipolytic action on triglyceride-rich lipoproteins carried by the blood stream (reviewed, Olivecrona and Olivecrona, 1995). Moreover, several lines of evidence indicate that LPL binds to cell surface HSPGs of a variety of cell types (Olivecrona and Olivecrona, 1995), and it has been proposed (Beisiegel, 1995) that HSPGs act as coreceptors, facilitating the transfer of lipoproteins bound via the lipase to specific receptors located in coated pits for internalization. Taken together, current evidence suggests that the role of cell surface HSPGs is critical to the complex molecular interactions that occur at the plasma membrane.

Cell surface HSPGs have different types of core protein, reflecting the varied locations and functions of these molecules (Ruoslahti, 1989; David, 1993; Elenius and Jalkanen, 1994). Human lung fibroblasts express at least five major structurally distinct cell surface HSPGs (Lories et al., 1989). They have been identified as syndecan-1 (Lories et al., 1992), fibroglycan or syndecan-2 (Marynen et al., 1989), a 125-kDa HSPG (that is probably related or identical to syndecan-3; Lories et al., 1989; Carey et al., 1992), amphiglycan, ryudocan or syndecan-4 (David et al., 1992a), and glypican (a glycosyl phosphatidylinositol-anchored HSPG) (David et al., 1990). The four syndecans together constitute a family of integral membrane HSPGs (Bernfield et al., 1992) that are expressed in different combinations in most cells (Lories et al., 1992). All known syndecans are transmembrane proteins anchored to the plasma membrane by a $24-25$ amino acid hydrophobic domain (David, 1993; Elenius and Jalkanen, 1994). They have structurally distinct extracellular domains, but the sequence of the cytoplasmic and transmembrane domains has been highly conserved during evolution (Bernfield et al., 1992). Recent evidence indicates that the transmembrane domain plus four conserved residues of the extracellular domain could mediate membrane oligomerization of syndecan-3 (Asundi and Carey, 1995). The presence of four invariant tyrosine residues in the cytoplasmic tails suggests roles for these domains in targeting and/or anchorage to intracellular structures, and they may mediate or participate in specific signal transmission from the extracellular ectodomain (Elenius and Jalkanen, 1994).

Previous studies have presented evidence for the association of cell surface proteoglycans with cytoskeletal structures in some cells (Carey and Todd, 1986). 
Syndecan-1, which has been studied in greatest detail, is reported to be anchored to the cytoskeleton on the basolateral surface of epithelial cells (Rapraeger et al., 1986; Leppä et al., 1992). Recently, Carey et al. (1994b) showed that expression of syndecan-1 by Schwann cells induced cytoskeletal organization and association of syndecan-1 with actin during cell spreading. Carey et al. also suggest (1994a) that the association of syndecan-1 with microfilaments is induced by aggregation and mediated by the cytoplasmic domain. In contrast, Miettinen and Jalkanen (1994) found that tail-less mutants were partly insoluble in Triton X-100 and concluded that the cytoplasmic domain of syndecan-1 is not responsible for actin interaction.

Recently, we have presented evidence that HSPGs that bind LPL and FGF-2 on the fibroblast cell surface are organized by the actin cytoskeleton (FernándezBorja et al., 1995). We also observed that, after incubation at $37^{\circ} \mathrm{C}, \mathrm{FGF}-2$ induces a change in the actin filament distribution, which occurs in parallel to the change in the cell surface distribution of HSPGs. In contrast, LPL induced a movement of HSPGs along the actin filaments without any change in the actin cytoskeleton distribution. Because the mode of interaction between HSPGs and the actin cytoskeleton could be important to understanding the functional role of these cell surface molecules, we extended our previous studies by using several microscopy methods. The results indicate that the binding of soluble ligands to the HS chains induces the cell surface aggregation of HSPGs over the actin cytoskeleton and that the ligand-HPSG complexes are nonrandomly distributed along the cortical actin filaments.

\section{MATERIALS AND METHODS}

\section{Cell Culture}

Human skin fibroblasts were cultured in Dulbecco's modified Eagle's medium (DMEM; BioWhittaker, Walkersville, MD), supplemented with $10 \%$ fetal calf serum (BioWhittaker), $2 \mathrm{mM}$ glutamine, and antibiotics. Cells between the 4 th and 15 th passage were plated onto culture dishes (35-mm diameter with gold grids covered with formvard coated with carbon for electron microscopy experiments) or glass coverslips (for fluorescence detection and cell surface-replica experiments), and used between the third and fifth day after seeding.

\section{Lipoprotein Lipase Purification and Biotinylation}

Bovine lipoprotein lipase was purified from milk as described (Bengtsson-Olivecrona and Olivecrona, 1991). For biotinylation, LPL was dialyzed at $4^{\circ} \mathrm{C}$ for $8 \mathrm{~h}$ against $0.1 \mathrm{M} \mathrm{Na}$-bicarbonate buffer, $\mathrm{pH} 8.8$, containing $1 \mathrm{M} \mathrm{NaCl}$. $\mathrm{N}$-Hydroxysuccinimide biotin (Sigma Chemical, St. Louis, MO) was added ( $25 \mu \mathrm{g} / \mathrm{mg}$ LPL) from a stock solution in dimethyl sulfoxide $(10 \mathrm{mg} / \mathrm{ml})$. After incubation at $4^{\circ} \mathrm{C}$ overnight, $1 \mathrm{M} \mathrm{NH}_{4} \mathrm{Cl}$ was added $(20 \mu \mathrm{l} / 250 \mu \mathrm{g}$ ester). After $15 \mathrm{~min}$ at $4^{\circ} \mathrm{C}$, the sample was diluted by the addition of $2 \mathrm{vol}$ of $10 \mathrm{mM}$ bistris buffer, $\mathrm{pH}$ 6.5, and was immediately applied to a column of heparin-Sepharose (Pharmacia, Uppsala, Sweden) that had been equilibrated in $10 \mathrm{mM}$ bistris, $\mathrm{pH} 6.5$, containing $0.3 \mathrm{M} \mathrm{NaCl}$. After a brief wash, the column was eluted by a salt gradient $(0.2-1.5 \mathrm{M}$
$\mathrm{NaCl}$ ). Biotinylated LPL appeared at the salt concentration expected for active LPL dimers. Activity measurements showed that the enzyme was fully active. For stabilization, $2 \mathrm{mg}$ of bovine serum albumin (BSA) $/ \mathrm{ml}$ was added before storage at $-70^{\circ} \mathrm{C}$.

\section{Binding Experiments}

For binding experiments, grids or coverslips were rinsed in DMEM at $4^{\circ} \mathrm{C}$, prechilled for $10 \mathrm{~min}$ at $4^{\circ} \mathrm{C}$ in the same medium, washed, and incubated for $30 \mathrm{~min}$ at $4^{\circ} \mathrm{C}$ in $2.5 \mu \mathrm{g} / \mathrm{ml}$ of bovine LPL in DMEM/20 mM HEPES, pH 7.4, containing 0.5\% BSA (Sigma). FGF-2 binding was performed with $1 \mu \mathrm{g} / \mathrm{ml}$ biotin-FGF-2 (Boehringer Mannheim Biochemica, Philadelphia, PA) in the conditions used for LPL binding. After being washed in $10 \mathrm{mM}$ phosphatebuffered saline (PBS), cells were fixed for $30 \mathrm{~min}$ in 3\% paraformaldehyde $/ 2 \%$ sucrose in $100 \mathrm{mM}$ phosphate buffer (PB). The effect of heparin on binding was assessed by incubating LPL in the presence of $100 \mathrm{U} / \mathrm{ml}$ heparin. Some of the binding experiments were performed with a monoclonal mouse IgM that recognizes an HSrelated antigen (10E4; David et al., 1992b) (provided by Professor G. David, University of Leuven, Belgium). Cells not subjected to the binding experiments were incubated for $30 \mathrm{~min}$ at $4^{\circ} \mathrm{C}$ without LPL or FGF-2, but in the same medium previously described for binding experiments, and then used to detect HSPG/actin distribution or as negative controls for the fluorescence or colloidal gold markers used.

For Triton X-100 treatments, the cells grown on coverslips or on gold grids were incubated or not with the indicated ligands as before and treated for $90 \mathrm{sec}$ at room temperature with extraction buffer containing $0.3 \%$ Triton X-100 (Sigma) in $20 \mathrm{mM}$ HEPES, $\mathrm{pH}$ $6.8,100 \mathrm{mM} \mathrm{NaCl}, 300 \mathrm{mM}$ sucrose, $3 \mathrm{mM} \mathrm{MgCl}, 1 \mathrm{mM} \mathrm{MgSO}_{4}$, and $1 \mathrm{mM}$ phenylmethylsulfonyl fluoride (PMSF). After two washes in $10 \mathrm{mM}$ PBS, cells were fixed with paraformaldehyde.

\section{Cross-linking Experiments}

Confluent human fibroblasts were washed three times in cold PBS before labeling the plasma membrane proteins with $0.5 \mathrm{mCi}{ }^{125} \mathrm{I}$ (Amersham International, Buckingham, UK) according to Saxena et al. (1991). The labeled cells were washed three times in cold PBS and allowed to react with $10 \mu \mathrm{l}$ of sulfosuccinimidyl-2-[p-azidosalicylamidolethyl-1,3-dithiopropionate (SASD; Pierce Europe, The Netherlands) $(0.4 \mathrm{mg} / \mathrm{ml}$ in dimethyl sulfoxide [DMSO] $)$ in a total volume of $10 \mathrm{ml}$ of cold PBS, in the dark, on ice for $2 \mathrm{~h}$. The nonbound cross-linker was eliminated by washing three times in cold PBS, and the cells were incubated with $20 \mu \mathrm{g}$ of biotin-LPL in $10 \mathrm{ml}$ of cold DMEM containing 1\% BSA, in the dark, on ice for $2 \mathrm{~h}$. The cells were then irradiated with UV light (wavelength $=360 \mathrm{~nm}$ ) for $15 \mathrm{~min}$. The medium was removed, and the cells were washed once in cold PBS, once in PBS containing $10 \mathrm{U} / \mathrm{ml}$ heparin, and again in PBS. The cells were harvested by scraping, pelleted by brief centrifugation ( 5 min at $1500 \mathrm{rpm}$ ), and dissolved in $1 \%$ Triton X-100 in cold Trisbuffered saline (TBS) containing $1 \mathrm{mM}$ PMSF, $2 \mathrm{mM}$ EDTA, $5 \mu \mathrm{g} / \mathrm{ml}$ aprotinin, and $5 \mu \mathrm{g} / \mathrm{ml}$ leupeptin. Insoluble material was separated by centrifugation for $15 \mathrm{~min}$ at $1500 \mathrm{rpm}$ and kept for further treatments as indicated below. The supernatant (defined as Triton X-100 soluble fraction) was applied to an avidin-agarose column (Sigma; $0.7 \mathrm{ml}$ settled gel). The column was washed with $20 \mathrm{ml}$ of TBS and eluted with $6 \mathrm{M}$ guanidinium- $\mathrm{HCl}, \mathrm{pH} 1.5$ (Cuatrecasas and Wilchek, 1968). The eluted radioactive fractions were pooled, dialyzed against $0.1 \mathrm{M}$ ammonium bicarbonate overnight, and freeze-dried. The powder was dissolved in TBS to obtain 1000 $\mathrm{cpm} / \mu \mathrm{l}$. Samples $(5 \mu \mathrm{l})$ were brought to $1 \mathrm{mM}$ PMSF and $2 \mathrm{mM}$ $\mathrm{CaCl}_{2}$ with $10 \times$ concentrated stock solutions and treated with heparinases I and III (Sigma; $10 \mathrm{mU} / \mathrm{ml}$ ) and chondroitinase $A B C$ (Boehringer Mannheim; $500 \mathrm{mU} / \mathrm{ml}$ ). The insoluble material after Triton X-100 treatment (defined as Triton X-100 insoluble fraction) was resuspended in actin depolymerization buffer (Pardee and Spudich, 1982) consisting of $2 \mathrm{mM}$ Tris- $\mathrm{HCl}, 0.2 \mathrm{mM} \mathrm{Na} \mathrm{A}_{2} \mathrm{ATP}, 0.2 \mathrm{mM}$ 
$\mathrm{CaCl}_{2}, 0.5 \mathrm{mM}$ 2-mercaptoethanol, and $0.005 \% \mathrm{NaN}_{3}, \mathrm{pH} 8.0$, for $1 \mathrm{~h}$ on ice. The concentration of Triton was brought to $1 \%$, and the supernatant was centrifuged for $15 \mathrm{~min}$ at $15000 \mathrm{rpm}$. This second supernatant was processed like the Triton X-100 soluble fraction. Total fibroblast PGs were semipurified by ion exchange chromatography in a cellulose, $O$-(diethylaminoethyl)-cellulose (DEAE)Sepharose column (Pharmacia) from Triton X-100 soluble and insoluble fractions of ${ }^{125} \mathrm{I}$-labeled cells obtained as described above. The column was washed with TBS and eluted with $50 \mathrm{mM}$ Tris- $\mathrm{HCl}$ buffer, pH 7.4, containing $0.9 \mathrm{M} \mathrm{NaCl}$. The eluted material was dialyzed against $0.1 \mathrm{M}$ ammonium bicarbonate and freeze-dried. The samples were analyzed in a $7.5 \%$ SDS-polyacrylamide gel under reducing conditions. The gel was stained with Coomassie brilliant blue, dried, and placed in contact with an x-ray film.

\section{Fluorescence Microscopy}

For detection of the HSPGs and cell-bound LPL or biotin-FGF-2, cells grown on coverslips were fixed for $30 \mathrm{~min}$ in $3 \%$ paraformaldehyde/ $2 \%$ sucrose in $100 \mathrm{mM}$ PB. After rinsing three times in 10 mM PBS, fixed cells were blocked and permeabilized with PBS/20 $\mathrm{mM}$ glycine containing $0.5 \% \mathrm{BSA}$ and $0.2 \%$ saponin for $10 \mathrm{~min}$. Different antibodies were then added to the cells, and all were incubated in PBS $/ 20 \mathrm{mM}$ glycine containing $0.5 \%$ BSA and $0.2 \%$ saponin. Depending on the experiment, two different primary antibodies against bovine LPL were used: a mouse monoclonal antibody (2H10; Fernández-Borja et al., 1995) and an affinity-purified polyclonal antibody (poly 66) raised in chicken (obtained from Dr. T. Olivecrona, University of Umeå, Sweden) (Buscà et al., 1995). The cells were incubated for $60 \mathrm{~min}$ at $37^{\circ} \mathrm{C}$ with the primary antibody $(10-20 \mu \mathrm{g} / \mathrm{ml})$, followed by rinsing in PBS and incubation for 45 min at $37^{\circ} \mathrm{C}$ with fluorescein isothiocyanate (FITC)-conjugated goat anti-mouse IgG (Boehringer Mannheim) or FITC-conjugated antichicken IgG (Sigma). Monoclonal antibody 10E4 was also used as the primary antibody to detect HS. After fixation as above, cells were incubated for $60 \mathrm{~min}$ at $37^{\circ} \mathrm{C}$ with the primary antibody (5 $\mu \mathrm{g} / \mathrm{ml}$ ), followed by rinsing in PBS $/ 20 \mathrm{mM}$ glycine and incubation for $45 \mathrm{~min}$ at $37^{\circ} \mathrm{C}$ with FITC-conjugated anti-mouse IgM (ICN ImmunoBiologicals, Costa Mesa, CA). Biotin-FGF-2 was detected with FITC-avidin (Vector, Burlingame, CA), and actin filaments were detected with tetramethyrhodamine isothiocyanate (TRITC)conjugated phalloidin (Sigma). No fluorescent labeling was seen in control experiments where cells were incubated with only secondary antibodies. The coverslips were finally washed in PBS, mounted with Immunofluore (ICN Biomedicals, Cleveland, $\mathrm{OH}$ ), and viewed on a Zeiss Axioskop equipped for epifluorescence. Black and white photographs were recorded on T-Max 400 film (Kodak, Rochester, NY). Results are representative of more than eight separate experiments with $>200$ cells analyzed for each condition, and the images were chosen to reflect the average patterns of immunofluorescence.

\section{Confocal Microscopy}

Two different confocal microscopes were used. Figures 3 and 8 were obtained with a laser-scanning confocal microscope (TCS 4D; Leica Lasertechnik $\mathrm{GmbH}$, Heidelberg, Germany) with an inverted microscope (Leitz DMIRBE) and a 63× (NA 1.4, oil) Leitz Plan-Apo objective. FITC and TRITC were simultaneously excited at 488- and 568-nm lines from a 75-mW krypton-argon laser, and two photomultipliers were used in parallel. A 488-/568-nm double-dichroic mirror was used as an excitation beam splitter, and a $580-\mathrm{nm}$ shortpass filter divided green and red fluorescence between the two photomultipliers. A 520-nm bandpass emission filter was used for FITC and a 590-nm longpass filter for TRITC. A correction for optical cross-talk was applied. Each image collected was the average of eight scans at the confocal microscope normal scan rate. Images of $512 \times 512$ pixels were stored on an erasable optical disk, visualized with a true color display screen, and then photographed on color slide film with a digital camera (Focus Graphics, Foster City,
CA). Under our conditions the $x, y$ resolution was $0.2 \mu \mathrm{m}$, and $x, z$ resolution was $0.5 \mu \mathrm{m}$ (Brakenhoff et al., 1985). Residual axial shifts between $488-$ and $568-\mathrm{nm}$ lines was $50 \mathrm{~nm}$. Colocalization analysis was performed by the Multi Colour software (version 2.0, Leica Lasertechnik $\mathrm{GmbH}$, Heidelberg, Germany). The two-dimensional confocal cytofluorogram in Figure 3 shows the correlation of the fluorescence signal from the two channels as a diagram: the fluorescence intensities of the green and red channels were represented on the $\mathrm{X}$-axis and $\mathrm{Y}$-axis, respectively (Demandolox and Davoust, 1995). The coincident labeling between the two single images was shown as the portion of the cytofluorogram located along the diagonal of the graph. The vertical (FITC) and horizontal (TRITC) portions of the graph are related with the single-labeled regions within the two single images. The selected colocalization area in the cytofluorogram was directly identified in the combined image in which the single-labeled areas were hidden.

Digital images of Figure 9 were collected with a PHOIBOS 1000 confocal microscope adapted to a Zeiss Axioskop microscope with a $63 \times$ (NA 1.4, oil) Zeiss Plan-Apo objective. FITC and TRITC were simultaneously excited by the 514-nm line of an argon ion laser. A double-dichroic mirror was used as an excitation beam splitter, and a 565-nm shortpass filter divided green and red fluorescence between the two photomultipliers. A 520-nm bandpass emission filter was used for FITC and a 570-nm longpass filter for TRITC. Image size of dual sections was $512 \times 512$ pixels; $x$,y calibration was 0.2 $\mu \mathrm{m} /$ pixel. For confocal quantification of HSPG distribution on the cell surface, we used the Imagespace software (version 3.1, Molecular Dynamics, Sunnyvale, CA). The distances were measured by drawing a line between consecutive clusters visualized over welldefined actin filaments (on a binary combined $x, y$ image). The same procedure was used to measure distances on $x, z$ sections. Statistical analysis (Biomedical Data Package Statistical software, California University Press, Los Angeles, CA) of the data in Figure 10 showed that the data followed a normal distribution.

\section{Electron Microscopy}

After Triton X-100 extraction, cells grown over electron microscopy grids were fixed for $30 \mathrm{~min}$ in $3 \%$ paraformaldehyde $/ 2 \%$ sucrose in $100 \mathrm{mM}$ PB and washed three times in $10 \mathrm{mM}$ PBS. They were then blocked for $10 \mathrm{~min}$ in PBS $/ 20 \mathrm{mM}$ glycine containing $0.5 \%$ BSA. Chicken anti-LPL (poly 66) was used as primary antibody to detect LPL. The grids were incubated for $60 \mathrm{~min}$ at room temperature with the primary antibody $(20 \mu \mathrm{g} / \mathrm{ml})$ in PBS $/ 20 \mathrm{mM}$ glycine containing $0.5 \% \mathrm{BSA}$, followed by rinsing in PBS/20 mM glycine and incubation with a rabbit anti-chicken IgG (Nordic Immunological Laboratories, Tilburg, The Netherlands). The cells were washed again in $\mathrm{PBS} / 20 \mathrm{mM}$ glycine and incubated for $45 \mathrm{~min}$ at room temperature in protein A-gold $(15 \mathrm{~nm}$ ) (purchased from Dr. J. Slot, University of Utrecht, The Netherlands). Antibody 10E4 was used either as a ligand or as primary antibody to detect HS, as indicated in RESULTS. When used as a ligand, cells were incubated with the antibody and then treated with Triton X-100, fixed as previously indicated, incubated with rabbit anti-mouse (Nordic), washed, and incubated for $45 \mathrm{~min}$ at room temperature with protein A-gold (15 $\mathrm{nm}$ ). When used to detect HSPGs on cells incubated with LPL after Triton X-100 extraction and paraformaldehyde fixation, grids were incubated for $60 \mathrm{~min}$ at room temperature with the $10 \mathrm{E} 4$ antibody in PBS $/ 20 \mathrm{mM}$ glycine containing $0.5 \% \mathrm{BSA}$, followed by rinsing in PBS and incubation with a rabbit anti-mouse antibody and protein A-gold $(15 \mathrm{~nm})$. In some experiments LPL or HS and actin were detected simultaneously. To this end, we double-labeled the cells with the primary and secondary (rabbit anti-chicken or rabbit antimouse IgM) antibodies to LPL and to HS used for single-labeling experiments and a monoclonal mouse IgG anti-actin (Boehringer Mannheim). For gold markers we used 15-nm gold-conjugated goat anti-rabbit (British Biocell, Cardiff, UK) to detect either LPL or HS and 10-nm gold-conjugated goat anti-mouse IgG (British Biocell). After immunolabeling, the grids were washed four times in PBS and 
fixed at room temperature for 60 min with $2 \%$ glutaraldehyde in 100 $\mathrm{mM}$ PB. They were then washed several times in $100 \mathrm{mM} \mathrm{PB}$ and post-fixed for $45 \mathrm{~min}$ with $1 \%$ osmium tetroxide. Grids were then dehydrated by passing through different solutions with increasing concentrations of ethanol, dried by the $\mathrm{CO}_{2}$ critical point method, and covered by evaporation with a thin carbon layer. The cells were viewed either on a Philips EM301 or on a Hitachi H600AB electron microscope. Results are representative of more than five separate experiments.

Surface replicas were obtained from cells grown on glass coverslips that were incubated either with LPL or 10E4 antibody, fixed with 3\% paraformaldehyde (but not treated with Triton-X 100), and incubated with secondary and gold markers as described above, post-fixed with glutaraldehyde, and processed as previously described. After drying by the critical point method, a carbon/platinum surface replica was produced in a Polaron E-7900 replica station, followed by the solubilization of the coverslips with hydrofluoric acid ( $3 \mathrm{~h}$, room temperature) and extraction of the organic material with $8 \%$ hypochloric sodium solution. The samples were washed in water, dried, and viewed on a Philips EM301 or a Hitachi $\mathrm{H} 600 \mathrm{AB}$ electron microscope. Results are representative of three separate experiments.

\section{RESULTS}

\section{Ligand-induced Organization of HSPGs}

As previously described (Fernández-Borja et al., 1995), we observed that human fibroblasts when incubated for $30 \mathrm{~min}$ at $4^{\circ} \mathrm{C}$ with bovine LPL (bLPL) had a striking cell surface distribution of LPL binding sites. The cells presented a fine punctate staining pattern consisting of small fluorescent clusters (Figure 1A) organized in parallel linear arrays that crossed the fibroblast cell surface longitudinally and codistributed with underlying actin filaments, as visualized by fluorescent phalloidin staining (Figure 1, A and B). In cells that were not incubated with LPL, the detection of cell surface HSPGs by the use of a monoclonal antibody (10E4) that recognizes an HS-related epitope (David et al., 1992b) showed that HSPGs did not codistribute with actin filaments (Figure 1, C and D). However, cells incubated with LPL under the same conditions as in Figure 1A, fixed and stained with the 10E4 antibody, presented an HSPG surface distribution (Figure 1E) identical to the pattern described for LPL binding sites (Figure 1A), which also codistributed with actin filaments (Figure 1, E and F). We did not detect any difference in actin cytoskeleton with or without surface-bound LPL (Figure 1, B, D, and F). These results suggest that HSPGs aggregated in response to ligand binding and then codistributed with actin cytoskeleton.

To confirm that cell surface binding sites for LPL corresponded to HSPGs, we performed several experiments. In cells incubated with LPL, as above, double immunostaining for LPL and HSPGs showed codistribution on the cell surface (Figure 2, A and B). The simultaneous incubation of LPL and heparin (a wellknown inhibitor of LPL binding to HSPGs) strongly reduced the LPL labeling on the cell surface (Figure
2C). Previously we had reported (Fernández-Borja et al., 1995) that heparinase treatment greatly reduces cell surface binding of FGF-2 and LPL. Here, because it is well described that HSPGs are known to act as lowaffinity receptors for FGF-2 and that FGF-2 binding sites had a similar surface distribution to that described for LPL (Fernández-Borja et al., 1995; Figure $2 \mathrm{E}$ ), we performed another binding competition experiment with LPL and a 10-molar excess of FGF-2. The LPL labeling was again reduced (Figure 2G), confirming the role of the membrane HSPGs as surface LPL binding sites. There was no apparent change in the actin cytoskeleton for cells with surface-bound FGF (Figure 2, F and $\mathrm{H}$ ) or treated with heparin (Figure 2D).

Confocal studies of cells with surface-bound LPL firmly settled the high degree of codistribution of LPL binding sites and actin cytoskeleton (Figure 3). Green and red pixel intensity distribution of cells incubated with bLPL as above and double-stained with anti-LPL FITC secondary antibodies (Figure 3A) and TRITCphalloidin (Figure 3B) was represented in a cytofluorogram (Figure 3D) by the use of multicolor analysis confocal software (Demandolox and Davoust, 1995). This histogram showed that most of the green fluorescence codistributed with red fluorescence (white pixels), whereas a higher proportion of red pixels was not codistributed. The selected area in Figure 3D (in white) was used to show the colocalization sites between LPL and actin (Figure 3C) in a binary combined image in which the single-labeled regions were hidden to show the colocalization sites between LPL and actin (Figure 3C). This indicates that after LPL binding most of the HSPGs associate with cortical actin cytoskeleton.

\section{Membrane HSPGs Bound to LPL Are Insoluble in Triton X-100}

Triton $X-100$ insolubility was used to study the association between membrane proteins or actin-binding proteins and the actin cytoskeleton. This detergent disrupts hydrophobic interactions, allowing such structures as cytoskeletal proteins and tightly associated proteins to remain insoluble. To determine whether cell surface HSPGs with bound LPL were insoluble in Triton X-100, we incubated fibroblast cells with LPL and treated them with Triton $X-100$. Double-fluorescence staining was performed with LPL antibodies and TRITC-phalloidin. Figure 4, A and B, shows that LPL remained anchored all over the actin microfilaments after Triton X-100 treatment. Parallel experiments performed by staining HS proteoglycans after LPL binding or incubating the cells with anti-HS confirmed that LPL binding sites remained insoluble after Triton X-100 extraction. To study the distribution of these bind- 

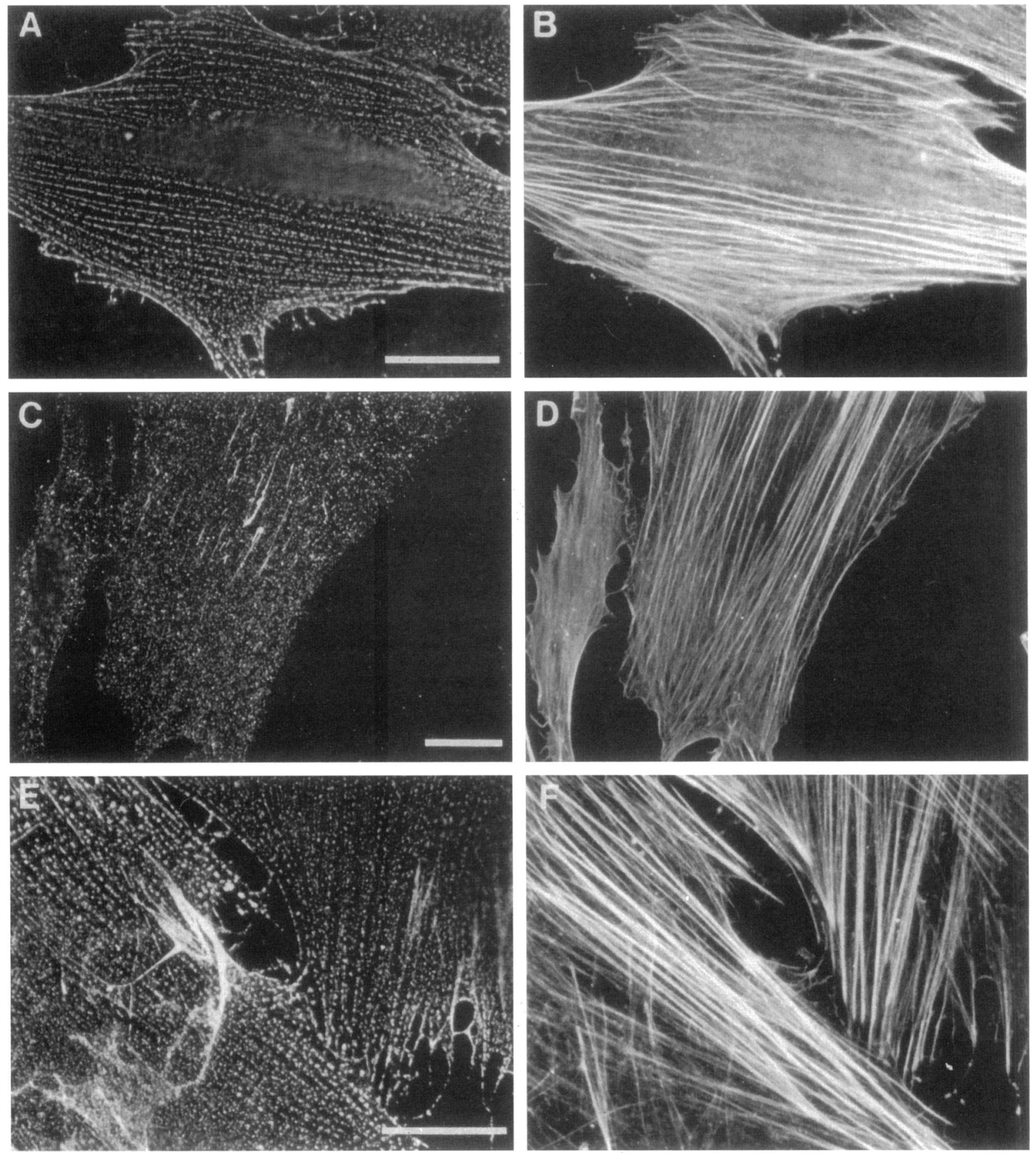

Figure 1. Distribution of cell surface-bound LPL and membrane HSPGs on human skin fibroblasts: colocalization with actin cytoskeleton LPL $(2.5 \mu \mathrm{g} / \mathrm{ml})$ was added to human skin fibroblasts grown on coverslips, and binding was allowed for $30 \mathrm{~min}$ at $4^{\circ} \mathrm{C}$ (A, B, E, and F). Other coverslips (C and D) were incubated for $30 \mathrm{~min}$ at $4^{\circ} \mathrm{C}$ without LPL. Cells were fixed, and LPL was detected with monoclonal antibodies, followed by FITC-conjugated goat anti-mouse IgG (A). HSPGs were detected with 10E4 antibody, followed by an FITC-conjugated anti-mouse IgM (C and E). Actin filaments were detected with TRITC-conjugated phalloidin (B, D, and F). Note the characteristic punctate distribution in parallel linear arrays on the cell surface that both LPL (A) and HSPGs show on cells with surface-bound LPL (E). These parallel linear arrays show colocalization with actin cytoskeleton (A, B, E, and F). In cells without surface-bound LPL, the HSPGs were randomly distributed (C) and did not show colocalization with actin cytoskeleton (C and D). The HSPGs of the extracellular matrix on the cell surface were also strongly stained but showed a filamentous type staining and not the characteristic punctate staining (C and E). (A and B) Bar, 50 $\mu \mathrm{m}$; (C and D) bar, $70 \mu \mathrm{m}$; (E and F) bar, $30 \mu \mathrm{m}$. 

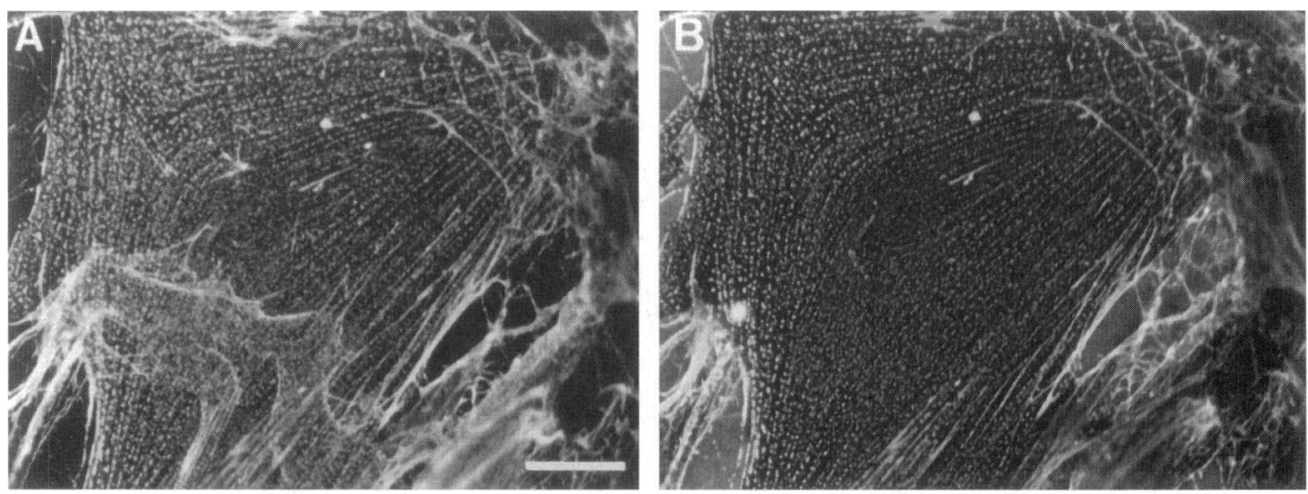

Figure 2. LPL binds to cell surface heparan sulfate proteoglycans of human skin fibroblasts. Binding of LPL (A, B, C, D, G, and $H$ ) was performed as described in Figure 1. BiotinFGF-2 $(1 \mu \mathrm{g} / \mathrm{ml}$; E and F) or 25 $\mu \mathrm{g} / \mathrm{ml}$ ( $\mathrm{G}$ and $\mathrm{H}$ ) was also added to some samples, and binding was allowed for $30 \mathrm{~min}$ at $4^{\circ} \mathrm{C}$. Cells were fixed, and biotin-FGF-2 was detected with FITC-conjugated avidin (E-G). Actin filaments (D, F, and $\mathrm{H}$ ) were stained with TRITC-conjugated phalloidin. (A and B) Double-immunofluorescence staining of LPL (A) and HS (B) performed with chicken polyclonal antibodies against LPL and FITC-conjugated rabbit anti-chicken IgG and monoclonal anti-HS (10E4 antibody) and TRITC-conjugated goat antimouse IgM. Simultaneous incubation of the fibroblasts with LPL and heparin $(100 \mathrm{U} / \mathrm{ml})$ dramatically decreased the surface-bound LPL (C) without any apparent change in the actin cytoskeleton (D). Surface-bound biotin-FGF-2 (E) showed a punctate distribution in parallel linear arrays that codistributed with the underlying actin cytoskeleton (F). Competition experiments between LPL and a 10-fold molar excess of FGF-2 decreased the cell surfacebound LPL (G) without any apparent change in the actin cytoskeleton (H). Photographs were taken with the same exposure times. Bar, $50 \mu \mathrm{m}$.
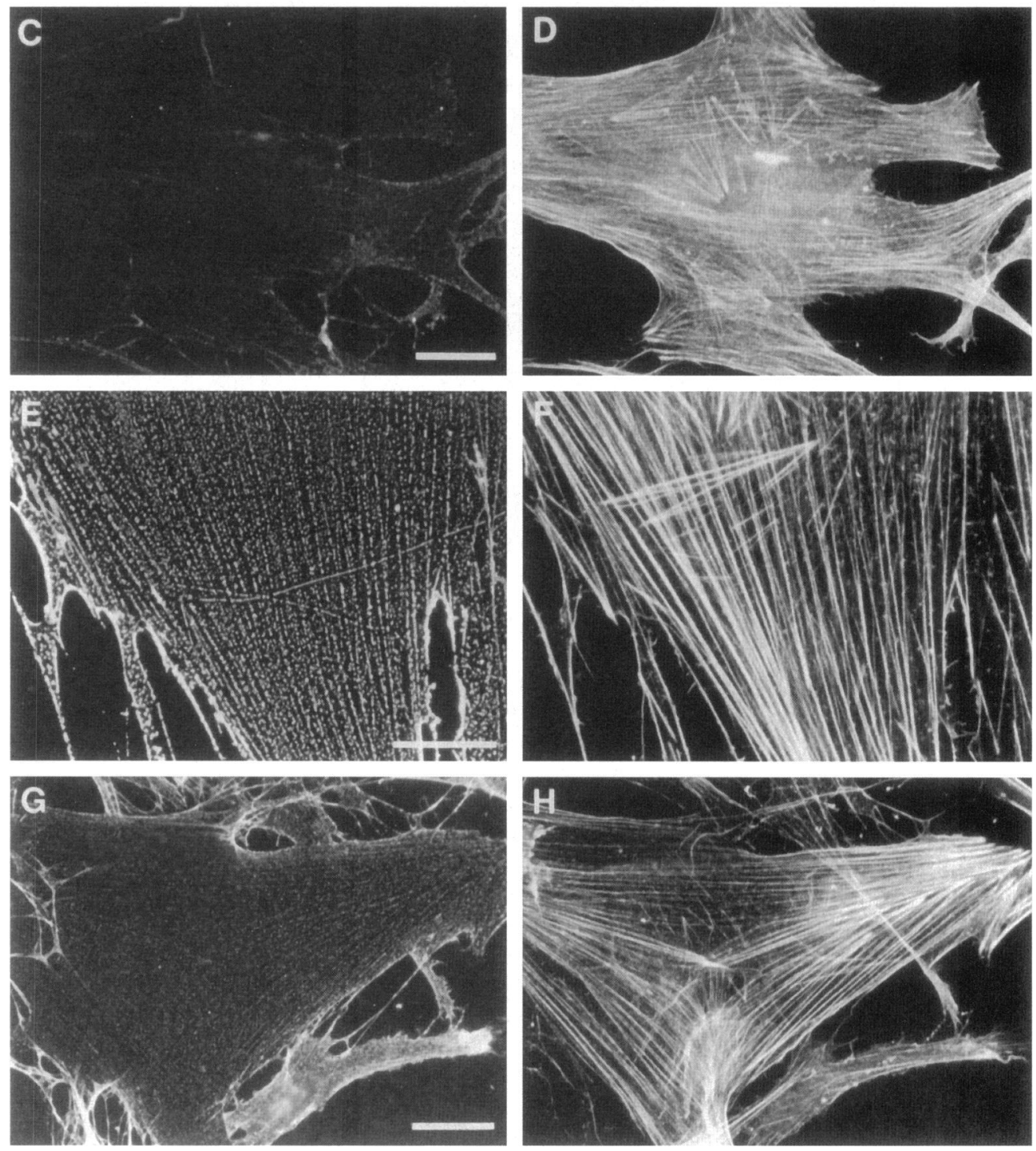

ing sites after Triton X-100 extraction, we performed immunoelectron microscopy on fibroblasts grown on electron microscopy grids, incubated at $4^{\circ} \mathrm{C}$ either with LPL or anti-HS, fixed, and immunostained with colloidal gold to reveal LPL or HS antibodies. By this approach, we observed a high number of HS clusters all over Triton X-100-resistant fibers (Figure 4, C and D). The HS clusters were composed of 

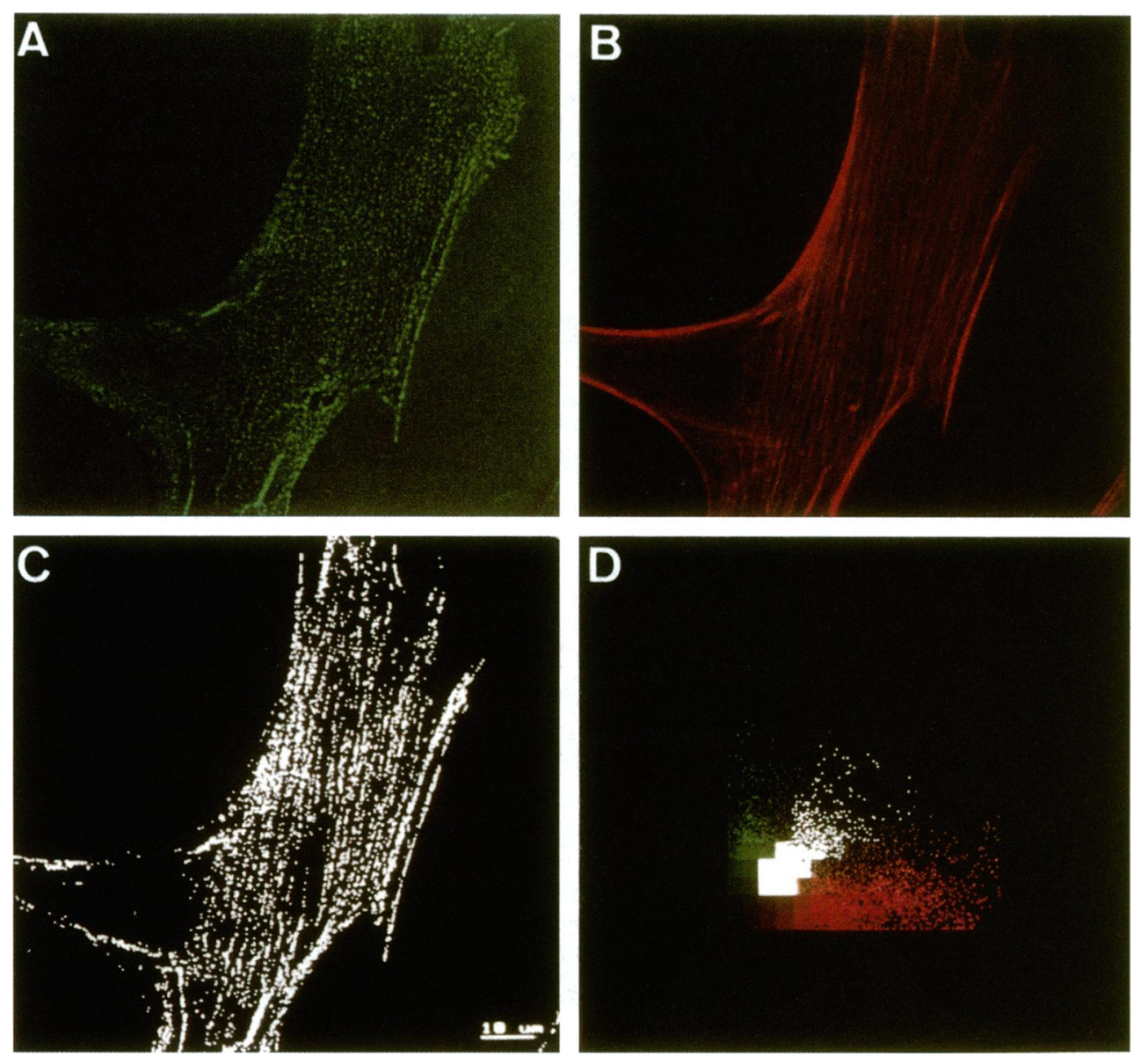

Figure 3. Confocal colocalization analysis of cell surface-bound LPL and actin filaments. Green and red pixel intensity distribution of cells incubated with bLPL as above and double-stained with anti-LPL FITC secondary antibodies (A) and TRITC-phalloidin (B) was represented in a cytofluorogram (D) with the use of multicolor analysis confocal software. The two-dimensional cytofluorogram shows the correlation of the two fluorescence signals as a diagram: fluorescence intensities of single-labeled region of FITC ( $Y$ axis) and TRITC ( $\mathrm{X}$-axis) and the colocalization area (white pixels along the diagonal of the graph). Note that most of the green fluorescence codistributes with red fluorescence, whereas there is a higher proportion of red pixels on the X-axis. The selected colocalization area in D (in white) was directly identified in the combined image $(C)$ in which the single-labeled regions were hidden. Bar, $10 \mu \mathrm{m}$. a variable number of gold particles (10-15 gold particles/cluster on average), and the fibers presented an average diameter of $20 \mathrm{~nm}$. In cells incubated with LPL and treated in the same way, LPL clusters resistant to Triton X-100 extraction were also anchored to fibers with a similar average diameter. To provide additional support to the conclusion that after Triton X-100 treatment both LPL and HS remained above the actin cytoskeleton, we performed double-immunogold localization studies with anti-actin and anti-LPL or anti-HS (Figure 4E). The results indicate that the fibers to which LPL or HS clusters remained attached after treatment with Triton X-100 corresponded to actin filaments.

To determine whether this insolubility of membrane HSPGs in Triton X-100 was due to their association with LPL, we incubated fibroblasts with and without LPL at $4^{\circ} \mathrm{C}$; after Triton X-100 extraction and fixation, we attempted to detect any HS remaining with the anti-HS. Cells with surface-bound LPL presented a large number of immunogold particles (as detected with anti-HS) anchored to the actin cytoskeleton (Figure 5A). In contrast, cells without LPL incubation had fewer immunogold particles (Figure 5B). Thus, mem- brane HSPGs complexed with LPL seemed to be more resistant to Triton X-100 extraction than membrane HSPGs without bound LPL, which suggests that the association between membrane HSPGs and actin cytoskeleton was stimulated by the surface binding of LPL.

To identify the human fibroblast membrane proteins that bind LPL and their insolubility in Triton $\mathrm{X}-100$, we radiolabeled the cell membranes with ${ }^{125} \mathrm{I}$, incubated them with biotin-LPL, and cross-linked them with the bifunctional reagent SASD. Samples were extracted with $1 \%$ Triton X-100 and insoluble material with an actin depolymerization buffer (Pardee and Spudich, 1982). After the plasma membrane was dissolved, biotin-LPL with cross-linked binding protein was isolated with an avidin-agarose column. After cleavage of the cross-linker and treatment with heparinase (I and III) and chondroitinase, samples were subjected to gel electrophoresis and autoradiography. When the samples were not treated with heparinase and chondroitinase, crosslinked proteins ran as high-molecular-mass smear (our unpublished observations). After enzyme treatment three major core proteins with appropriate 

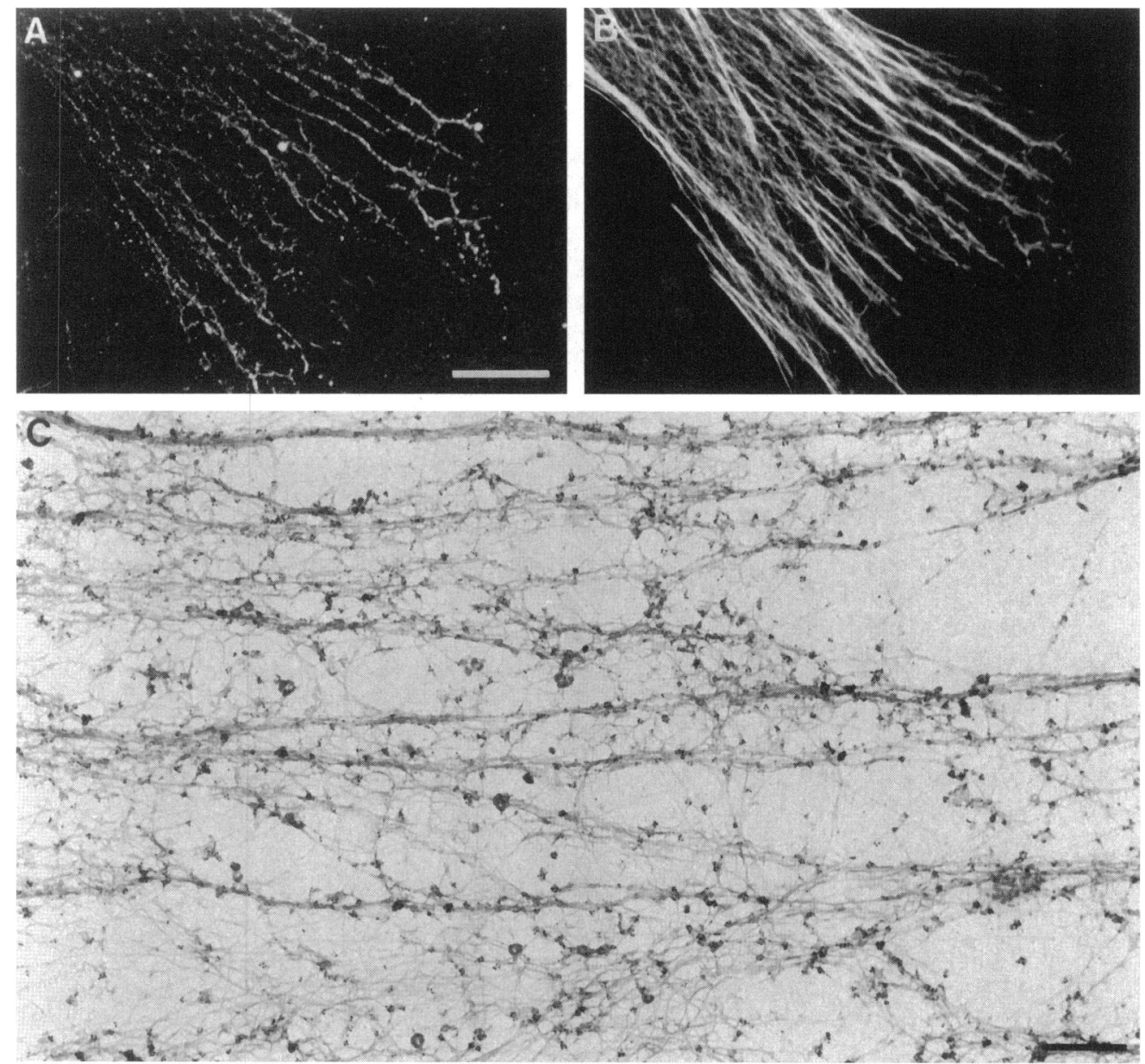

bound to LPL are insoluble in Triton X-100. After LPL binding, the cells were treated with Triton X-100, as indicated in MATERIALS AND METHODS. Cells were fixed, and fluorescence staining for LPL (A) and actin filaments (B) was performed as in Figure 1. For electron microscopy studies, cells grown on grids were incubated with LPL and fixed, and HSPGs (15-nm gold) (C and D) were detected by immunogold staining, post-fixed, and dehydrated, as indicated in MATERIALS AND METHODS. (E) LPL (15-nm gold, large arrows) and actin (10-nm gold, small arrows) were detected by double-immunogold procedures. Note that both LPL (E) and HS (D) clusters were resistant to Triton X-100 extraction and remained associated with Triton X-100resistant cytoplasmic fibers. (A and B) Bar, $50 \mu \mathrm{m}$; (C) bar, 1 $\mu \mathrm{m}$; (D and E) bar, $0.25 \mu \mathrm{m}$.

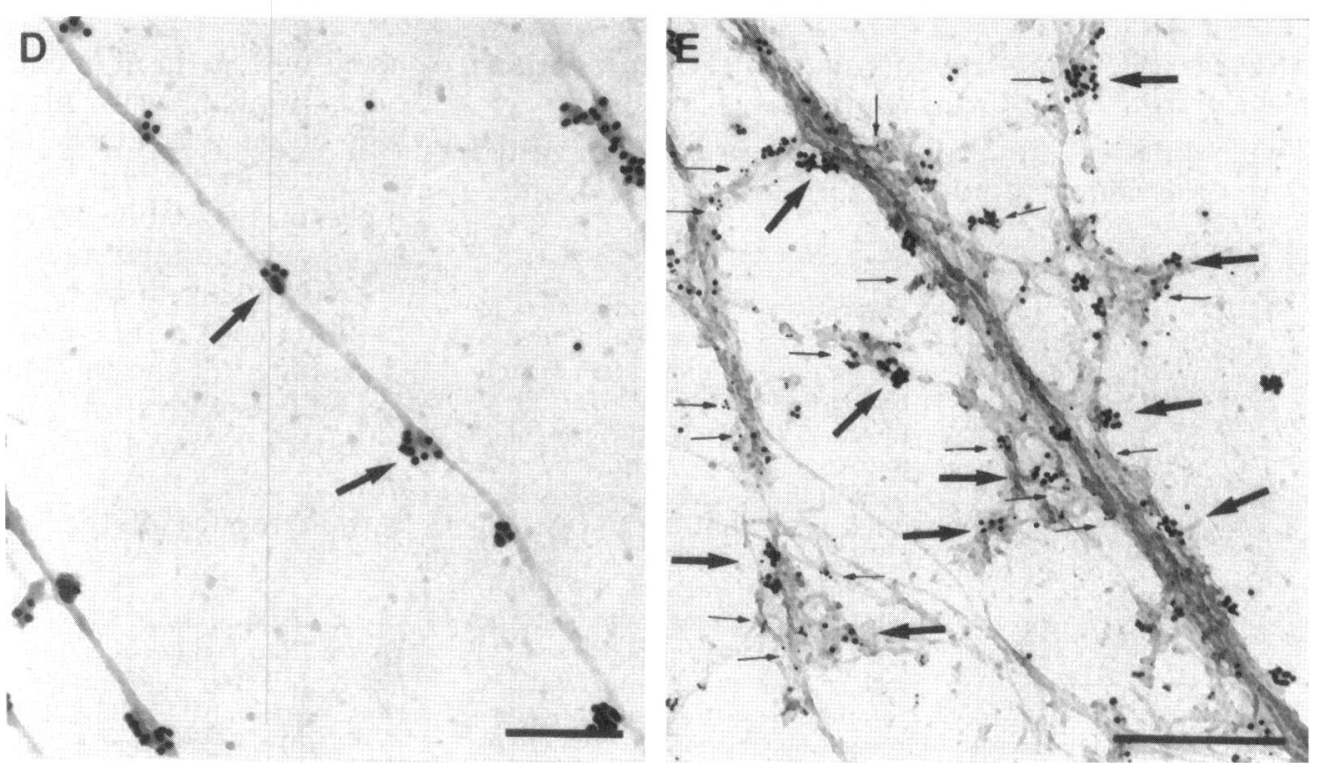

molecular masses of 64,88 , and $125 \mathrm{kDa}$ were observed in the Triton X-100 insoluble fraction (Figure 6 , lane 4). However, a significantly lower amount of cross-linked protein was recovered in the Triton $\mathrm{X}-100$ soluble fraction, as shown in Figure 6, lane 2. 

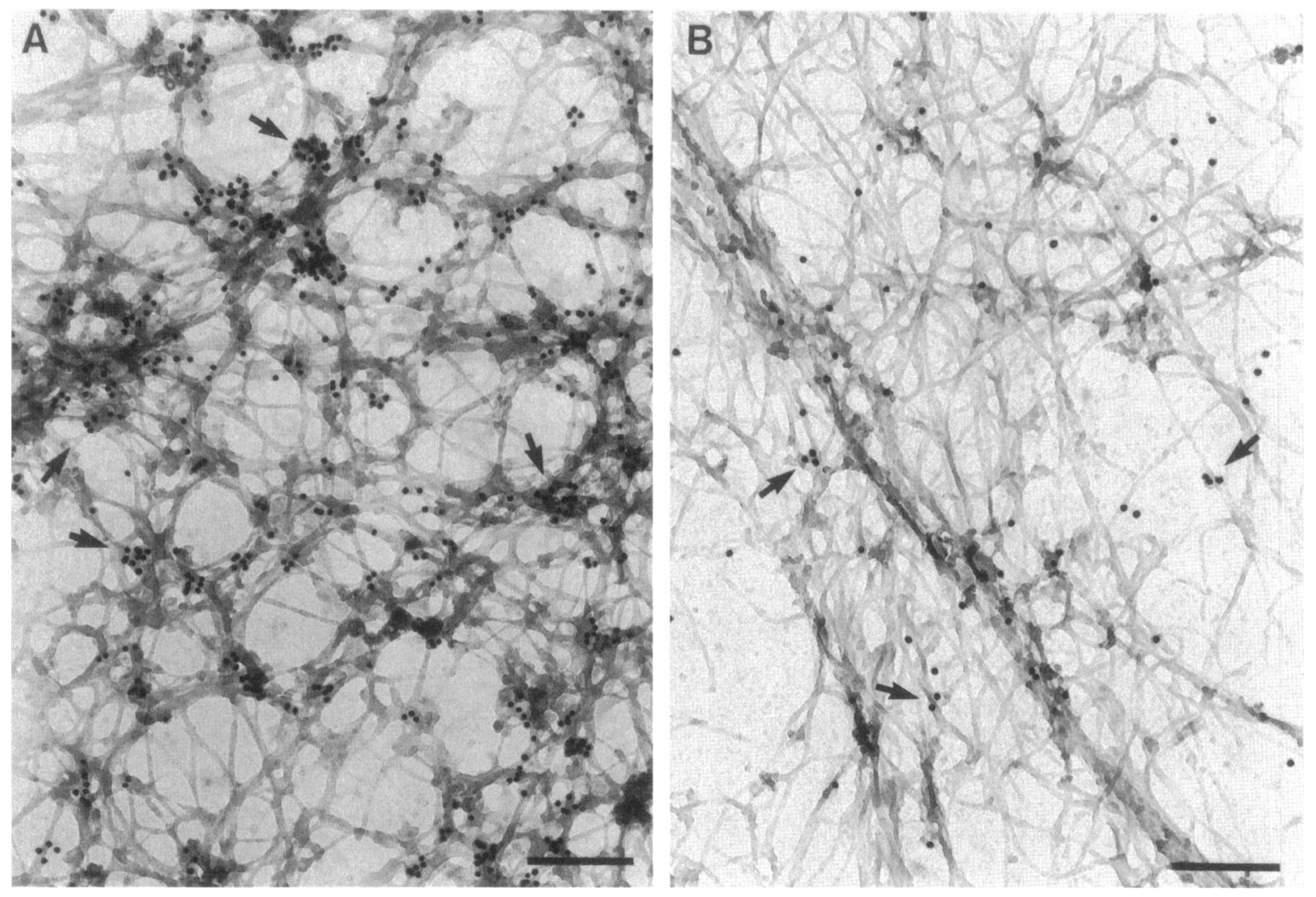

Figure 5. Cell surface binding of LPL reduces Triton X-100 extraction of HSPGs. Cells grown on electron microscopy grids were incubated with (A) or without (B) LPL, treated with Triton X-100 as in Figure 4, and fixed; HS was detected with monoclonal anti-HS (10E4) and immunogold (15-nm gold), as described in MATERIALS AND METHODS. Cells with surface-bound LPL (A) showed a higher number of HS immunogold particles associated with Triton X-100-resistant fibers (arrows) than cells without surface-bound LPL (B). Bar, 0.25 $\mu \mathrm{m}$.

\section{Membrane HSPGs Are Nonrandomly Arranged along the Cortical Actin Cytoskeleton}

The results of the previous experiments suggested that, after ligand binding, HSPGs aggregated, inter-

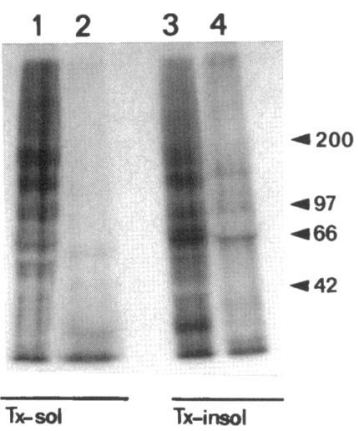

Figure 6. Cross-linking of biotinylated LPL to ${ }^{125}$ I-labeled fibroblast cell surface. Confluent human fibroblasts were labeled with ${ }^{125} \mathrm{I}$, allowed to react with the cross-linking reagent $\mathrm{SASD}$, incubated with biotin-LPL, and processed as indicated in MATERIALS AND METHODS to obtain Triton X-100 soluble and insoluble fractions. Total fibroblast proteoglycans from these fractions were semipurified by DEAE ion exchange chromatography. Samples were treated with chondroitinase and heparinase before gel electrophoresis. Shown are total (lane 1) and cross-linked to LPL (lane 2) proteoglycans in Triton X-100 soluble fraction and total (lane 3 ) and cross-linked to LPL (lane 4) proteoglycans from Triton X-100 insoluble fraction. Three major bands of 125,88, and $64 \mathrm{KDa}$ were obtained after actin depolymerization treatment (lane 4). Results are representative of two separate experiments. acted with actin filaments, and were distributed periodically along actin fibers. However, one disadvantage of using Triton X-100 in the study of any protein anchored to the cytoskeleton is that this anchor can be more or less labile, if the protein is partly soluble. Moreover, because several cell components are solubilized during this treatment, the structure of the remaining cells can be altered. To obtain a high-resolution image of the plasma membrane organization of the HSPGs with surface-bound LPL and to provide an additional control of our electron microscopy results after Triton X-100 extraction, we made a platinum/ carbon replica of the cell surface of the fibroblasts

Figure 7 (on facing page). Cell surface distribution of membrane HSPGs: platinum/carbon surface replicas. Cells grown on coverslips were incubated with LPL as in Figure 4, and HSPGs (A and C) or LPL (B) were detected, as indicated in MATERIALS AND METHODS, by immunogold $(15 \mathrm{~nm})$. Samples were post-fixed, dehydrated, and dried. Platinum/carbon replicas were made in a Polaron replica station, followed by the solubilization of the coverslips and extraction of the organic material. Note than both HS (A and B) and LPL (C) were present as large aggregates (arrows) associated with cytoplasmic fibers. (A) Bar, $1 \mu \mathrm{m}$; (B and C) bar, $0.5 \mu \mathrm{m}$. 

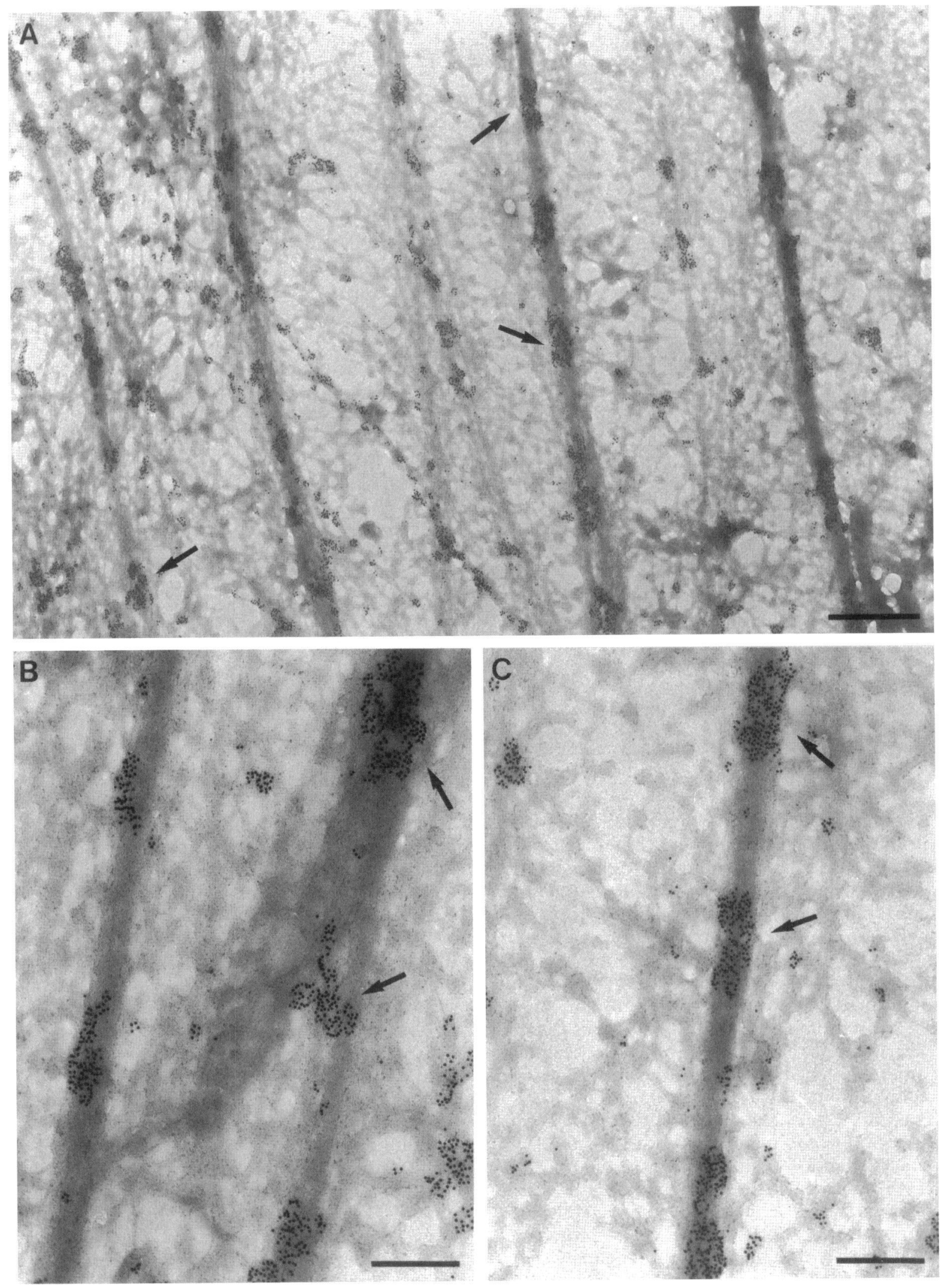

Figure 7. 

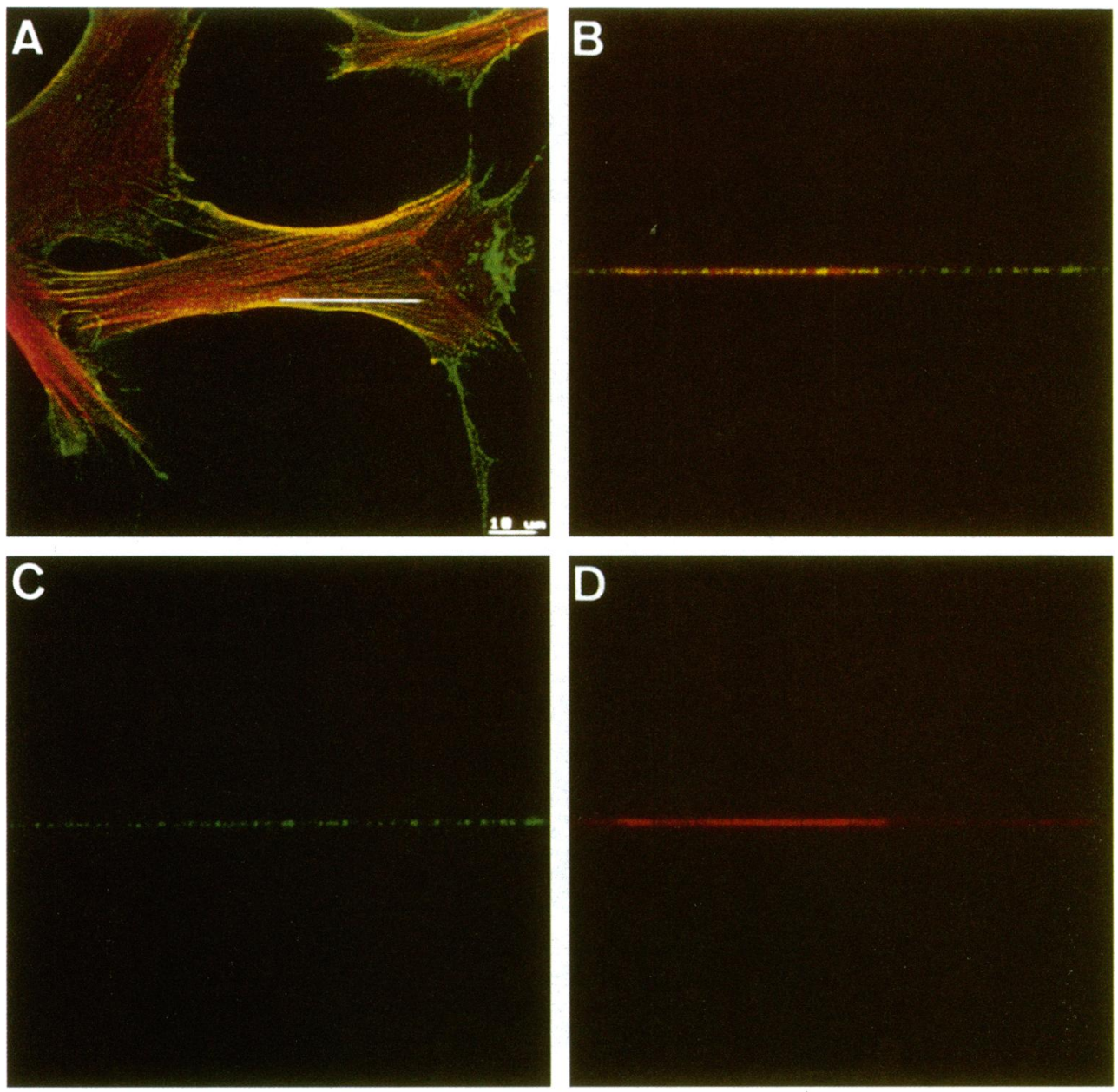

Figure 8. Confocal microscopy analysis of the distribution of LPL binding sites along individual actin filaments. Fibroblasts were incubated with LPL at $4^{\circ} \mathrm{C}$, as described above, and fixed; double fluorescence was performed to reveal distribution of LPL and actin filaments. Horizontal sections $(\mathrm{x}, \mathrm{y} ; \mathrm{A})$ and vertical $(\mathrm{x}, \mathrm{z} ; \mathrm{B})$ confocal sections were obtained. White line in B indicates where vertical section was performed. Simultaneous confocal imaging of vertical sections along individual actin filaments showed that LPL immunofluorescence was distributed as spots along actin filaments (yellow points in Figure 7B). Bar, $10 \mu \mathrm{m}$. incubated either with LPL or with anti-HS not treated with Triton X-100. The surface replica showed a detailed image on which membrane aggregates of HSPGs were distributed in a highly organized manner along thick $(\sim 200 \mathrm{~nm})$ and thin $(\sim 50 \mathrm{~nm})$ cytoplasmic fibers, which probably corresponded to cortical actin filaments (Figure 7A). However, because it is not possible to perform double-labeling experiments by this technique to detect HSPGs and actin simultaneously, we cannot substantiate that all HSPGs were associated to the actin filaments. By this approach it was also evident that the spacing between the centers of the clusters along a fiber was quite regular $(\sim 2 \mu \mathrm{m})$.

Figures 8 and 9 show the results obtained by confocal microscopy in cells incubated with LPL and with anti-HS, respectively. To study the periodic distribution of LPL binding sites, we incubated fibroblasts with LPL at $4^{\circ} \mathrm{C}$, as described above, and fixed them. Double fluorescence was used to reveal the distribution of LPL and actin filaments simultaneously. Horizontal $(x, y$; Figure 8A) and vertical $(x, z$; Figure 8B) confocal sections were obtained and analyzed. Simul- taneous confocal imaging of vertical sections along individual actin filaments showed that LPL immunofluorescence was distributed as spots along the actin filaments (yellow points in Figure 8B).

To study the distribution of HSPGs along the actin cytoskeleton, we performed two types of experiment. In one, cells were incubated with anti-HS at $4^{\circ} \mathrm{C}$ and then fixed and immunostained with FITC-conjugated secondary antibodies and TRITC-phalloidin (Figure 9, A, C, and E). In the other, fibroblasts were fixed, and then double-fluorescence staining was performed with anti-HS, FITC-conjugated secondary antibodies, and TRITC-phalloidin (Figure 9, B, D, and F). When the cells were incubated with anti-HS at $4^{\circ} \mathrm{C}$, colocalization between HSPGs and actin filaments was high (colocalization pixels in Figure 9A, in white, and 9C, in yellow). When only colocalization spots were represented (Figure 9C), the alignment of HS immunofluorescence staining became clear. In contrast, in fixed immunostained cells colocalization between actin filaments and HSPGs was lower, as indicated by the number and alignment of yellow spots (Figure 9B, in 

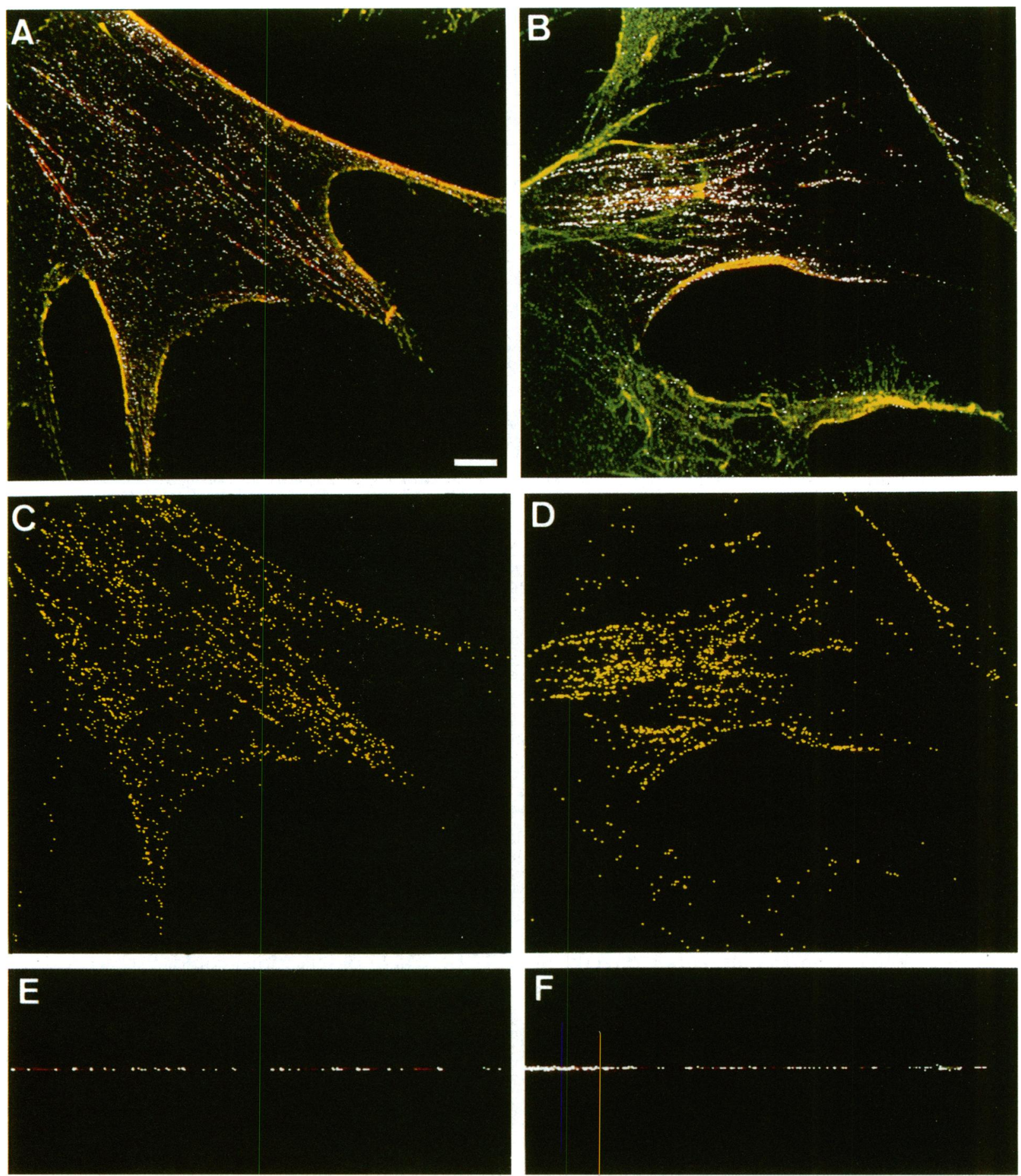

Figure 9. Confocal microscopy analysis of HSPG distribution along actin cytoskeleton. In left panels (A, C, and E) cells were incubated with anti-HS at $4^{\circ} \mathrm{C}$, fixed, and immunostained with FITC-conjugated secondary antibodies and TRITC-phalloidin. In right panels (B, D, and F) cells were fixed, and double-fluorescence staining experiments were performed with anti-HS FITC-conjugated secondary antibodies and TRITC-phalloidin. (A and B) Simultaneous confocal imaging of horizontal sections. (C and D) Binary combined images in which the single-labeled regions were hidden to show the colocalization distribution of HSPGs and actin. (E and F) Dual vertical sections obtained by following the same confocal procedure as in Figure 7. Colocalization is shown in white (A, B, E, and F) or in yellow pixels (C and D) by using the selected area on a cytofluorogram. 
white, and 9C, in yellow). These results add further support to the hypothesis that the interaction between HSPGs and actin filaments was induced by ligand binding. In addition, the pattern and distribution of HS immunostaining obtained in vertical sections was also different. In cells incubated with anti-HS, the fluorescent spots were separated by regular distances (Figure 9E), similar to those previously obtained in LPL-incubated cells (Figure 8B). In fixed cells the fluorescent spots were more irregularly distributed (Figure 9, B, D, and F) when compared with nonfixed cells (Figure 9, A, C, and E).

The distance between membrane HSPG clusters over actin filaments was quantified on different confocal images ( $x, y$ and $x, z$ sections) obtained from the experiments reported above. In cells with binding of LPL or anti-HS, clusters were uniformly spaced. The mean distance between LPL fluorescent spots was 2.4 $\mu \mathrm{m}$ ( $\pm 0.70, \mathrm{n}=283$; Figure $10 \mathrm{~A})$, which was very close to that found in cells incubated with anti-HS (Figure 10B) $(x=2.2 \mu \mathrm{m} \pm 0.6 ; n=345)$. In contrast, the average distance between HSPGs from fixed cells was more variable (Figure 10C) $(x=3.9 \mu \mathrm{m} \pm 2.3 ; n=$ 189). In $x, z$ sections the values obtained were similar to those obtained in $x, y$ sections: in cells incubated with anti-HS the mean distance obtained was $2.6 \mu \mathrm{m}$ ( $\pm 0.7 ; n=268)$, and in fixed and immunostained cells with anti-HS the mean was $5.51 \mu \mathrm{m}( \pm 3.9 ; \mathrm{n}=129)$. Because the average distance values were much more uniform in cells that had been incubated with anti-HS or LPL than in fixed immunostained cells, the results suggest that ligand binding could induce a periodic arrangement of HSPGs along the actin cytoskeleton.

\section{DISCUSSION}

The cortical actin cytoskeleton has a crucial role in plasma membrane molecular organization interacting with transmembrane components either directly or through actin-binding proteins. Increasing evidence suggests that these interactions are important not only for the maintenance of cell architecture but also for signal transduction and regulation of cell growth (Luna and Hitt, 1992). It has become clear that the distribution and assembly of membrane proteins in the plasma membrane are, in part, regulated through the membrane-associated cytoskeleton (Hitt and Luna, 1994). Recently we have shown that two wellknown heparin-binding molecules (LPL and FGF-2) bind to cell surface HSPGs, which in turn are organized by the actin cytoskeleton (Fernández-Borja et al., 1995). In the present study we have extended our previous observations and presented evidence that the interaction of HSPGs with the underlying actin cytoskeleton is indeed induced by ligand binding, probably through an aggregation mechanism, and follows a well-ordered periodic distribution along actin filaments.

Several lines of evidence allowed us to conclude that the association of HSPGs with actin filaments was induced by ligand binding. 1) In the absence of the ligand, HSPGs were irregularly distributed over the fibroblast surface without any codistribution with actin cytoskeleton. 2) In the presence of ligand, most of the HSPGs codistributed with the actin cytoskeleton and were resistant to Triton X-100 extraction. 3) Crosslinking antibodies against an HS-related epitope also induced the association with the actin cytoskeleton. This aggregation and also the actin codistribution of the HSPGs took place rapidly at $4^{\circ} \mathrm{C}$ : it could be detected even after $5 \mathrm{~min}$ of incubation with ligands. It is very likely that the nature of the cell surface HSPGs detected in our study was not unique, because LPL and FGF-2 bind to several HS proteoglycans (Misra et al., 1994; Rapraeger et al., 1994). In the present study we found that LPL can be cross-linked to at least three different proteoglycans with molecular masses of 125 , 88 , and $64 \mathrm{kDA}$, which could represent syndecan-3, syndecan-1, and glypican, respectively (Lories et al., 1989; Carey et al., 1992). This result suggests that, in fibroblasts, LPL might bind to a subset of proteoglycans.

Provided that the 64-kDa protein is glypican (a lipid-anchored proteoglycan), our finding that the 64$\mathrm{kDa}$ protein was resistant to extraction with Triton $\mathrm{X}-100$ was to be expected. It is well known that glycosyl phosphatidylinositol-anchored proteins are not extracted by nonionic detergents (Hooper and Turner, 1988; Glenney and Zokas, 1989; and others), possibly because of their association to insoluble membrane lipids. On the other hand, recent evidence (Mayor et al., 1994; Mayor and Maxfield, 1995) indicates that GPI proteins are clustered to caveolae after antibody crosslinking or detergent treatment. In turn, caveolae are associated to the actin cytoskeleton (Lisanti et al., 1994). These observations could also account for the appearance of LPL-bound glypican in the insoluble fraction.

Previous reports have described colocalization of syndecan-1 and actin cytoskeleton in epithelial or spreading cells (Rapraeger et al., 1986; Bernfield et al., 1992; Leppä et al., 1992; Carey et al., 1994a). Recently, Carey et al. (1994b) have demonstrated that antibodies against core protein of syndecan-1 (a CS/HS member of the cell surface PG family), expressed in Schwann cells, induce association with the underlying actin cytoskeleton. Here, by using an antibody against the glycosaminoglycan chain (HS), we have obtained similar results for fibroblast HSPGs and also have observed that ligands of HS induce the same effect. It was also suggested by Carey et al. (1994b) that the aggregation of the cell surface proteoglycans could be induced by multiligand proteins like extracellu- 
A

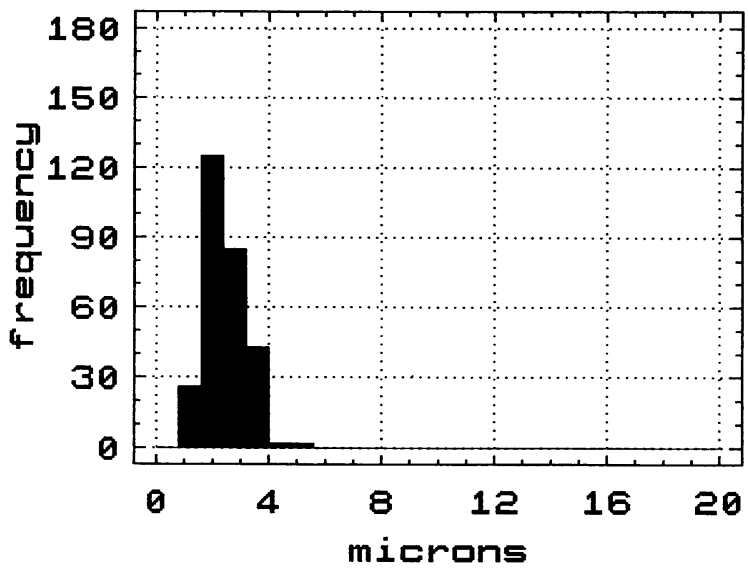

B

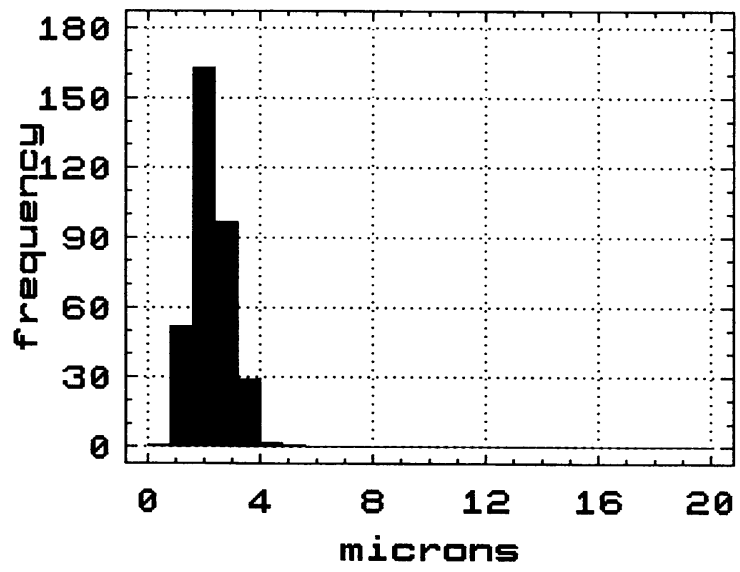

C

PF/aHS

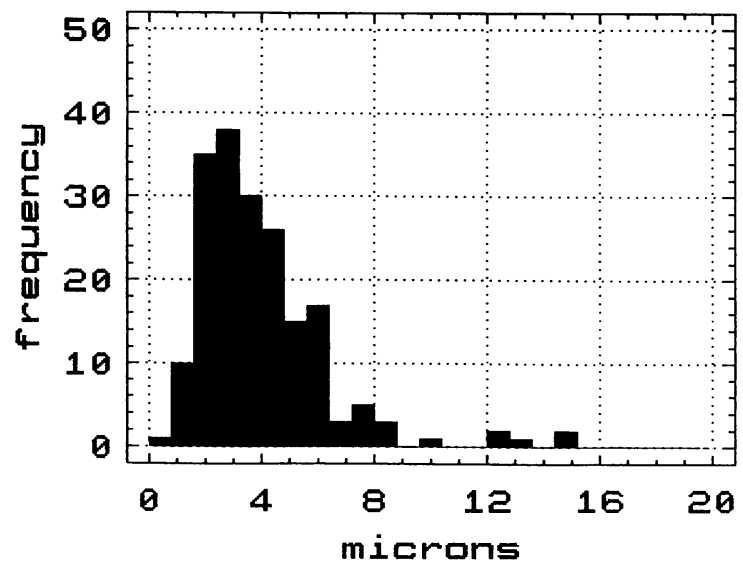

lar adhesive glycoproteins. However, our previous (Fernández-Borja et al., 1995) and present results indicate that this aggregation-induced process was not dependent on the type of ligand used, because we obtained similar sizes of HSPGs-clusters and a similar degree of actin codistribution when the cells were incubated with either an immunoglobulin (IgM) anti-HS or LPL or FGF-2. Thus, it could be physiologically relevant that soluble ligands to HSPGs also induce their aggregation and cytoskeletal association. Other authors have recently addressed the association of syndecan-1 with the Triton X-100 insoluble fraction in CHO-transfected cells (Miettinen and Jalkanen, 1994). They reported a partial insolubility of wild-type and tail-less syndecan, which was not affected by increasing temperature or by cytochalasin D treatment, concluding that this was not dependent on cytoskeletal association. In view of the present results, this partial insolubility could be due to the absence of ligand. However, it cannot be ruled out that PGs present a different plasma membrane organization, depending on the cell type and their actin cytoskeleton organization.

Induced oligomerization of integral membrane proteins and receptors is a common occurrence in the plasma membrane (Wells, 1994), and in many cases it is involved in signal transduction, such as in ligandinduced oligomerization of growth factor receptors (Schlessinger and Ulrich, 1992). Similarly, clustering of $\beta_{1}$ integrins with fibronectin, adhesive peptides, or anti-integrin antibodies induces rapid receptor aggregation and accumulation of a variety of actin-binding proteins and triggers phosphorylation of pp $120^{\mathrm{FAK}}$ (Miyamoto et al., 1995a,b). To date, it has been understood that several members of the membrane PG family have a tendency to oligomerize to dimers or tetramers. This has been reported for syndecan-2 (Marynen et al., 1989), syndecan-3 ( $\mathrm{N}$-syndecan; Asundi and Carey, 1995), and CD44 (Geppert and Lipsky, 1991). Interestingly, the core motif in syndecan-3 that confers self-association (the last four amino acids of the extracellular domain plus the transmembrane domain) are conserved among the known mammalian members of the syndecan family (Asundi et al., 1995). The example of CD44 is particularly illustrative,

Figure 10. Distribution of HSPGs on fibroblast cell surface. Cells were processed to detect LPL binding sites and HS and analyzed by confocal microscopy, as indicated in Figures 7 and 8. Quantification was performed with Imagespace Software on confocal images $(x, y)$ by drawing an interactive line between consecutive clusters. (A) Mean distance between LPL binding sites in cells incubated with LPL and then fixed with paraformaldehyde (PF) and immunostained was $2.4 \mu \mathrm{m} \pm 0.7(n=283)$. (B) The distance between HSPGs as detected by binding of anti-HS (aHS) in nonfixed cells was $2.2 \mu \mathrm{m} \pm 0.6(n=345)$. (C) The distance between HSPGs in fixed cells and immunostained with anti-HS was $3.9 \mu \mathrm{m} \pm 2.3(\mathrm{n}=$ 189). 
because it has been shown that the interaction of CD44 with actin cytoskeleton is enhanced by clustering (Geppert and Lipsky, 1991) and that the CD44-actin interaction is mediated by the binding to members of the ERM (erzin, radixin, merlin, and moesin) family to the cytoplasmic tail of CD44 molecules (Tsukita et al., 1994). This family of actin-binding proteins is localized just beneath the plasma membrane, and it seems to be involved in the molecular mechanisms of actin filament-plasma membrane interactions (Sato et al., 1992; Tsukita et al., 1992). From our results, it is tempting to speculate that the effects of the glycosaminoglycan chain mediated by ligand binding could induce core protein self-association, which in turn facilitates PG association to the underlying actin cytoskeleton. The functional role of the cytoskeletal interaction of cell surface HSPGs remains unclear. However, we are learning from other cell matrix and cell-cell transmembrane receptor molecules like integrins (Miyamoto et al., 1995a,b; Yamada and Miyamoto, 1995) and cadherins (Gumbiner, 1995; Shibamoto et al., 1995) that aggregation and interaction with the actin cytoskeleton could initiate signal transduction cascades. In support of this, FGF-2 induces actin filament reorganization (Fernández-Borja et al., 1995), and antibodymediated aggregation of syndecan-1 results in the redistribution of the actin filaments (Carey et al., 1994b).

One major observation in the present study was the regular alignment of ligand-induced aggregated HSPGs along actin filaments. Large aggregates were found on 200-nm-thick fibers (which could represent stress fibers) and were aligned at variable intervals of $\sim 2-2.5 \mu \mathrm{m}$ (as measured by confocal microscopy and in surface replicas). However, irrespective of the distance, the results indicate that the interaction of HSPGs along the actin fibers occurs at discrete sites on the microfilament bundles. This suggests periodic microdomains in the cortical actin cytoskeleton that could be responsible for the HSPG interaction. Several cytoplasmic actin-binding molecules showed a periodic distribution along stress fibers. Tropomiosin and caldesmon (Yamashiro-Matsumura and Matsumura, 1988; Tanaka et al., 1993), $\alpha$-actinin (Jackson et al., 1989), myosin I, and myosin II (Conrad et al., 1993; Tanaka et al., 1993), among others, have been reported to be distributed periodically along actin filaments in nonmuscle cells. Thus, the alignment of ligand-induced HSPGs along actin filaments may reflect the interaction with actin-binding proteins. Considering all these results together, it is possible that such periodic arrangement may regulate cytoplasmic activities and/or plasma membrane interactions between heparin-binding proteins and other plasma membrane receptors.

\section{ACKNOWLEDGMENTS}

We thank David Bellido for his constant help and expert assistance, David García and Dr. Carmen Lopez for their expert technical assistance, and Dr. Guido David for providing antibodies to heparan sulfate and for useful discussions. We also thank Dr. Mercè Monfar and Robin Rycroft for expert editorial help. This work was supported by the Comision Interministerial de Ciencia y Tecnologia (grant SAF-92-0897; PB94-1548), the Fondo de Investigaciones Sanitarias from Ministerio de Sanidad (grant 93/0423E), the TeleMarató TV3 de Catalunya, the Bank of Sweden Tercentenary Foundation, and by a BIOMED program from the European Community (grant PL-921243). R.M. was partially supported by the Erasmus program from the European Community.

\section{REFERENCES}

Asundi, V.K., and Carey, D.J. (1995). Self-association of $N$-syndecan (syndecan-3) core protein is mediated by a novel structural motif in the transmembrane domain and ectodomain flanking region. J. Biol. Chem. 270, 26404-26410.

Beisiegel, U. (1995). Receptors for triglyceride-rich lipoproteins and their role in lipoprotein metabolism. Curr. Opin. Lipidol. 6, 117-122.

Bengtsson-Olivecrona, G., and Olivecrona, T. (1991). Phospholipase activity of milk lipoprotein lipase. Methods Enzymol. 197, 345-356.

Bernfield, M., Kokenyesi, R., Kato, M., Hinkes, M.T., Spring, J., Gallo, R.L., and Lose, E.J. (1992). Biology of syndecans. Annu. Rev. Cell Biol. 8, 365-393.

Brakenhoff, G.J., Van der Voort, H.T.M., Van Spronsen, E.A., Limnemans, W.A.M., and Nanninga, N. (1985). Three-dimensional chromatin distribution in neuroblastoma nuclei shown by confocal scanning laser microscopy. Nature 317, 748-749.

Buscà, R., Pujana, M.A., Pognonec, P., Auwerx, J., Deeb, S.S., Reina, M., and Vilaró, S. (1995). Absence of N-glucosylation at asparagine 43 in human lipoprotein lipase induces its accumulation in the rough endoplasmic reticulum and alters this cellular compartment. J. Lipid. Res. 36, 939-951.

Carey, D.J., Evans, D.M., Sthal, R.C., Asundi, V.K., Conner, K.J., Garbes, P., and Cizmeci-Smith, G. (1992). Molecular cloning and characterization of $\mathrm{N}$-syndecan, a novel transmembrane heparan sulphate proteoglycan. J. Cell Biol. 117, 191-201.

Carey, D.J., Stahl, R.C., Cizmeci-Smith, G., and Asundi, V.K. (1994a). Syndecan-1 expressed in Schwann cells causes morphological transformation and cytoskeletal reorganization and associates with actin during cell spreading. J. Cell Biol. 124, 161-170.

Carey, D.J., Stahl, R.C., Tucker, B., Bendt, K.A., and Cizmeci-Smith, G. (1994b). Aggregation-induced association of syndecan-1 with microfilaments mediated by the cytoplasmic domain. Exp. Cell Res. $214,12-21$.

Carey, D.J., and Todd, M.S. (1986). A cytoskeleton-associated plasma membrane heparan sulfate proteoglycan in Schwann cells. J. Biol. Chem. 16, 7518-7525.

Conrad, P.A., Giulano, K.A., Fisher, G., Collins, K., Matsudaira, P.T., and Taylor, D.L. (1993). Relative distribution of actin, myosin I, and myosin II during the wound healing response of fibroblasts. J. Cell Biol. 120, 1381-1391.

Cuatrecasas, P., and Wilcheck, M. (1968). Single-step purification from egg white by affinity chromatography on biotin-Sepharose columns. Biochem. Biophys. Res. Commun. 33, 235-239.

David, G. (1993). Integral heparan sulfate proteoglycans. FASEB J. 7 , 1023-1030. 
David, G., Bai, X.M., Schuren, B.D., Cassiman, J-J., and Berghe, H.V. (1992a). Developmental changes in heparan sulfate expression: in situ detection with mAbs. J. Cell Biol. 119, 961-975.

David, G., Lories, V., Decock, B., Marynen, P., Cassiman, J.-J., and Berghe, H.V. (1990). Molecular cloning of a phosphatidylinositolanchored membrane heparan sulfate proteoglycan from human lung fibroblasts. J. Cell Biol. 111, 3165-3176.

David, G., Scheren, B.V., Marynen, P., Cassiman, J.-J., and Berghe, H.V. (1992b). Molecular cloning of amphiglycan-a novel integral membrane heparan sulfate proteoglycan expressed by epithelial and fibroblast cells. J. Cell Biol. 118, 961-969.

Demandolox, D., and Davoust, J. (1995). Multicolor analysis in confocal immunofluorescence microscopy. J. Trace Microprobe Tech. 13, 217-225.

Elenius, K., and Jalkanen, M. (1994). Function of the syndecans: a family of cell surface proteoglycans. J. Cell Sci. 107, 2975-2982.

Fernández-Borja, M., Bellido, D., Makiya, R., David, G., Olivecrona, G., Reina, M., and Vilaró, S. (1995). Actin cytoskeleton of fibroblasts organizes surface proteoglycans that bind basic fibroblast growth factor and lipoprotein lipase. Cell Motil. Cytoskeleton 30, 89-107.

Geppert, T.D., and Lipsky, P.E. (1991). Association of various T cell surface molecules with the cytoskeleton. Effect of cross-linking and activation. J. Immunol. 146, 3298-3305.

Gitay-Goren, H., Soker, S., Vlodavsky, I., and Neufeld, G. (1992). The binding of vascular endothelial growth factor to its receptors is dependent on cell surface-associated heparin-like molecules. J. Biol. Chem. 276, 6093-6098.

Glenney, J.R., and Zokas, L. (1989). Novel tyrosine kinase substrates from Rous sarcoma virus-transformed cells are present in the membrane skeleton. J. Cell Biol. 108, 2401-2408.

Gumbiner, B.M. (1995). Signal transduction by $\beta$-catenin. Curr. Opin. Cell Biol. 7, 634-640.

Higashiyama, S., Chang, P., and Silvestein, S.C. (1993). Heparinbinding EGF-like growth factor stimulation of smooth muscle cell migration: dependence on interactions with cell surface heparan sulfate. J. Cell Biol. 122, 933-940.

Hitt, A.L., and Luna, E.J. (1994). Membrane interactions with the actin cytoskeleton. Curr. Opin. Cell Biol. 6, 120-130.

Holmes, W.E., et al. (1992). Identification of heregulin, a specific activator of $\mathrm{p} 185^{\mathrm{erb} 2}$. Science 256, 1205-1210.

Hooper, N.M., and Turner, A.J. (1988). Ectoenzymes of the kidney microvillar membrane: differential solubilization by detergents can predict a glycosyl-phosphatidylinositol membrane anchor. Biochem J. 250, 865-869.

Hynes, R.O. (1992). Integrins-versatility, modulation, and signaling in cell adhesion. Cell 69, 11-25.

Jackson, P., Smith, G., and Critchley, D.R. (1989). Expression of muscle-type alpha-actinin cDNA clone in non-muscle cells. Eur. J. Cell Biol. 50, 162-169.

Kan, M., Wang, F., Xu, J., Crabb, J.W., Hou, J., and McKeehan, W.L. (1993). An essential heparin-binding domain in the fibroblast growth factor receptor kinase. Science 259, 1918-1921.

Kjellén, L., and Lindahl, U. (1991). Proteoglycans: structures and interactions. Annu. Rev. Biochem. 60, 443-473.

Klagsbrun, M., and Baird, A. (1991). A dual receptor system is required for basic fibroblast growth factor activity. Cell 67, 229-231.

Leppä, S., Mali, M., Miettinen, H.M., and Jalkanen, M. (1992). Syndecan expression regulates cell morphology and growth of mouse mammary epithelial tumor cells. Proc. Natl. Acad. Sci. USA 89, 932-936.
Lisanti, M.P., Scherer, P.E., Tang, Z.-L., and Sangiacomo, M. (1994). Caveolae, caveolin, and caveolin-rich membrane domains: a signaling hypothesis. Trends Cell Biol. 4, 231-235.

Lories, V., Cassiman, J.-J., Berghe, H.V., and David, G. (1989). Multiple distinct membrane heparan sulfate proteoglycans in human lung fibroblasts. J. Biol. Chem. 264, 7009-7016.

Lories, V., Cassiman, J.-J., Berghe, H.V., and David, G. (1992). Differential expression of cell surface heparan sulfate proteoglycans in human mammary epithelial cells and lung fibroblasts. J. Biol. Chem. $67,1116-1122$.

Luna, E.J., and Hitt, A.L. (1992). Cytoskeleton-plasma membrane interactions. Science 258, 955-964.

Marynen, P., Zhang, J., Cassiman, J.J., Berghe, H.V., and David, G. (1989). Partial primary structure of the 48- and 90- kilodalton core proteins of cell surface-associated heparan sulfate proteoglycans of lung fibroblasts. Prediction of an integral membrane domain and evidence for multiple distinct core proteins at the cell surface of human lung fibroblasts. J. Biol. Chem. 264, 7017-7024.

Mayor, S., and Maxfield, F.R. (1995). Insolubility and redistribution of GPI-anchored proteins at cell surface after detergent treatment. Mol. Biol. Cell 6, 929-944.

Mayor, S., Rothberg, K.G., and Maxfield, F.R. (1994). Sequestration of GPI-anchored proteins in caveolae triggered by cross-linking. Science 264, 1948-1951.

Miettinen, H.M., and Jalkanen, M. (1994). The cytoplasmic domain of syndecan-1 is not required for association with Triton X-100insoluble material. J. Cell Sci. 107, 1571-1581.

Misra, K.B., Kim, K.C., Cho, S.Y., Low, M.G., and Bensadoun, A. (1994). Purification and characterization of adipocyte heparan sulfate proteoglycans with affinity for lipoprotein lipase. J. Biol. Chem. $269,23838-23844$.

Miyamoto, S., Akiyama, S.K., and Yamada, K.M. (1995a). Synergistic roles for receptor occupancy and aggregation in integrin transmembrane function. Science 267, 883-885.

Miyamoto, S., Teramoto, H., Coso, O.A., Gutkind, J.S., Burbelo, P.D., Akiyama, S.K., and Yamada, K.M. (1995b). Integrin function: molecular hierarchies of cytoskeletal and signaling molecules. J. Cell Biol. 131, 791-805.

Olivecrona, G., and Olivecrona, T. (1995). Triglyceride lipases and atherosclerosis. Curr. Opin. Lipidol. 6, 291-305.

Olwin, B.B., and Rapraeger, A. (1992). Repression of myogenic differentiation by aFGF, bFGF, and K-FGF is dependent on cellular heparan sulfate. J. Cell Biol. 118, 631-639.

Pardee, J.D., and Spudich, J.A. (1982). Purification of muscle actin. Methods Enzymol. 85, 164-181.

Rapraeger, A.C. (1993). The coordinated regulation of heparan sulfate, syndecans, and cell behaviour. Curr. Opin. Cell Biol. 5, 844854.

Rapraeger, A.C., Guimond, S., Krufka, A., and Olwin, B.B. (1994). Regulation by heparan sulfate in fibroblast growth factor signaling. Methods Enzymol. 245, 219-240.

Rapraeger, A.C., Jalkanen, M., and Bernfield, M. (1986). Cell surface proteoglycan associates with the cytoskeleton at the basolateral cell surface of mouse mammary epithelial cells. J. Cell Biol. 103, 26832696.

Rapraeger, A.C., Krufka, A., and Olwin, B.B. (1991). Requirement of heparan sulfate for bFGF-mediated fibroblast growth and myoblast differentiation. Science 252, 1705-1708.

Ruoslahti, E. (1989). Proteoglycans in cell regulation. J. Biol. Chem. 264, 13369-13372. 
Sakagushi, K., Yanagishita, M., Takaeuchi, Y., and Aurbach, G.D. (1991). Identification of heparan sulfate proteoglycan as a high affinity receptor for acidic fibroblast growth factor (aFGF) in a parathyroid cell line. J. Biol. Chem. 266, 7270-7278.

Sato, N., Funayama, N., Nagafuchi, A., Yonemura, S., Tsukita S. and Tsukita, S. (1992). A gene family consisting of ezrin, radixin, and moesin: its specific localization at actin filament/plasma membrane association sites. J. Cell Biol. 103, 131-143.

Saxena, U., Klein, M.G., and Goldberg, I.J. (1991). Identification and characterization of the endothelial cell surface lipoprotein lipase receptor. J. Biol. Chem. 266, 17516-17521.

Schlessinger, J., Lax, I., and Lemmon, M. (1995). Regulation of growth factor activation by proteoglycans: what is the role of the low affinity receptors? Cell $83,357-360$.

Schlessinger, J., and Ulrich, A. (1992). Growth factor signaling by receptor tyrosine kinases. Neuron 9, 383-391.

Shibamoto, S., Hayakawa, M., Takeuchi, K., Hori, T., Miyazawa, K., Kitamura, N., Johnson, K.R., Wheelock, M.J., Matsuyoshi, N., Takeichi, M., and Ito, F. (1995). Association of p120, a tyrosine kinase substrate, with E-cadherin/catenin complexes. J. Cell Biol. 128, 949 957.

Tanaka, J., Watanabe, T., Nakamura, N., and Sobue, K. (1993). Morphological and biochemical analyses of contractile proteins (ac- tin, myosin, caldesmon, and tropomyosin) in normal and transformed cells. J. Cell Sci. 104, 595-606.

Tsukita, S., Oishi, K., Sato, N., Sagara, J., Kawai, A., and Tsukita, S. (1994). ERM family members as molecular linkers between the cell surface glycoprotein CD44 and actin-based cytoskeletons. J. Cell Biol. 126, 391-401.

Tsukita, S., Tsukita, S., Nagafuchi, A., and Yonemura, S. (1992). Molecular linkage between cadherins and actin filaments in cell-tocell adherent junctions. Curr. Opin. Cell Biol. 4, 834-839.

Wells, J.A. (1994). Structural and functional basis for hormone binding and receptor oligomerization. Curr. Opin. Cell Biol. 6, 163-173.

Yamada, K.M., and Miyamoto, S. (1995). Integrin transmembrane signaling and cytoskeletal control. Curr. Opin. Cell Biol. 7, 681-689.

Yamashiro-Matsumura, S., and Matsumura, F. (1988). Characterization of 83-kilodalton nonmuscle caldesmon from cultured rat cells: stimulation of actin binding of nonmuscle tropomyosin and periodic localization along microfilaments like tropomyosin. J. Cell Biol. 106, 1973-1983.

Yayon, A., Klagsbrun, M., Esko, J.D., Leder, P., and Ornitz, D.M. (1991). Cell surface heparin-like molecules are required for binding of basic fibroblast growth factor to its high affinity receptor. Cell 64, 841-848. 